\title{
Spatial Variation of Cladophora Epiphytes in the Nan River, Thailand
}

\author{
Karnjana Ruen-Pham ${ }^{1}$, Linda E. Graham ${ }^{2}$ and Anchittha Satjarak 1,*(D) \\ 1 Plants of Thailand Research Unit, Department of Botany, Faculty of Science, Chulalongkorn University, \\ Bangkok 10330, Thailand; k.ruenpham@gmail.com \\ 2 Department of Botany, University of Wisconsin-Madison, 430 Lincoln Drive, Madison, WI 53706, USA; \\ lkgraham@wisc.edu \\ * Correspondence: anchittha.s@chula.ac.th; Tel.: +66-2218-6169; Fax: +66-2252-8979
}

Citation: Ruen-Pham, K.; Graham, L.E.; Satjarak, A. Spatial Variation of Cladophora Epiphytes in the Nan River, Thailand. Plants 2021, 10, 2266. https://doi.org/10.3390/ plants10112266

Academic Editor: Giuseppe Fenu

Received: 29 September 2021

Accepted: 20 October 2021

Published: 22 October 2021

Publisher's Note: MDPI stays neutral with regard to jurisdictional claims in published maps and institutional affiliations.

Copyright: (c) 2021 by the authors. Licensee MDPI, Basel, Switzerland. This article is an open access article distributed under the terms and conditions of the Creative Commons Attribution (CC BY) license (https:// creativecommons.org/licenses/by/ $4.0 /)$.
Abstract: Cladophora is an algal genus known to be ecologically important. It provides habitats for microorganisms known to provide ecological services such as biosynthesis of cobalamin (vitamin $\mathrm{B}_{12}$ ) and nutrient cycling. Most knowledge of microbiomes was obtained from studies of lacustrine Cladophora species. However, whether lotic freshwater Cladophora microbiomes are as complex as the lentic ones or provide similar ecological services is not known. To illuminate these issues, we used amplicons of $16 \mathrm{~S}$ rDNA, $18 \mathrm{~S}$ rDNA, and ITS to investigate the taxonomy and diversity of the microorganisms associated with replicate Cladophora samples from three sites along the Nan River, Thailand. Results showed that the diversity of prokaryotic and eukaryotic members of Cladophora microbiomes collected from different sampling sites was statistically different. Fifty percent of the identifiable taxa were shared across sampling sites: these included organisms belonging to different trophic levels, decomposers, and heterotrophic bacteria. These heterogeneous assemblages of bacteria, by functional inference, have the potential to perform various ecological functions, i.e., cellulose degradation, cobalamin biosynthesis, fermentative hydrogen production, ammonium oxidation, amino acid fermentation, dissimilatory reduction of nitrate to ammonium, nitrite reduction, nitrate reduction, sulfur reduction, polyphosphate accumulation, denitrifying phosphorus-accumulation, and degradation of aromatic compounds. Results suggested that river populations of Cladophora provide ecologically important habitat for microorganisms that are key to nutrient cycling in lotic ecosystems.

Keywords: Cladophora; microbiome; Nan River; lotic environment; ecological services

\section{Introduction}

Cladophora (Kützing) Kützing is a cosmopolitan filamentous green algal genus widely distributed in freshwater, marine, and brackish shoreline environments across arctic and tropical regions [1-4]. Freshwater species occur as filaments attached to various kinds of substrates, from rock surface to shells of arthropods, and as free-floating algal masses. This alga survives in water bodies of a wide range of nutrients levels, from the ultra-oligotrophic to the highly eutrophic, and a wide variety of conditions of attachment substrate, light intensity, water temperature, and water velocity [5].

Having unique characteristics and a high surface area, Cladophora is known as an ecological engineer that provides habitats for several other organisms, e.g., bacteria, archaea, protists, microalgae, fungi, and invertebrates, promoting complex epiphytic communities [6-10]. Previous studies found that these heterogeneous assemblages of living organisms displayed various ecological interactions, e.g., [4,6,7,9-11]. Predation in the algal microbiome could be inferred from the presence of organisms belonging to different trophic levels in the food chain, e.g., producers, herbivores, carnivores, and omnivores, representing organisms of diverse supergroups, e.g., Viridiplantae, Euglenozoa, Stramenopiles, Alveolata, Rhizaria, Amoebozoa, and Eumetazoa [12]. Competition could be inferred from the alternations or shifts of taxonomic richness and abundance in comparative studies 
e.g., [11]. For example, dynamic changes in bacterial populations were observed during the algal growth season [6] or when Cladophora grew in media supplemented with different chemical compositions [11], as it happens spontaneously also in the wild plant populations of terrestrial environments, where the same taxon to a different chemical soil composition may produce a different chemotype [13].

Among these ecological interactions, mutualism in the Cladophora microbiomes has been the most well studied, e.g., [4,6,7,9-11]. The mutualistic relationship was inferred from the presence of taxonomic markers and protein-coding genes in metagenomic analyses. Studies suggested that the photoautotrophs, i.e., the host Cladophora and epiphytic diatoms, provide habitats and exopolysaccharides that serve as resources for other heterotrophic bacteria and fungi. In return, the heterotrophic bacteria and fungi supply the phycosphere with vitamin $\mathrm{B}_{12}$, inorganic minerals, and gases needed for the growth of Cladophora and other microbes in the association [4,6,9-11].

Algal structural features, wide distribution, and ecological importance made the Cladophora microbiome a popular research topic during the past decade. Microbiome studies of the freshwater lacustrine Cladophora were conducted for algal samples collected from many locales, e.g., [4,6,9-11,14-20]. However, the microbiomes of freshwater Cladophora living in lotic water bodies have not been investigated.

In lotic environments, the directional flow of water makes nutrient cycling distinctively different from that of lentic environments. In temperate lakes, nutrients influx, e.g., debris, dissolved organic matter, and inorganic minerals, is mainly from seasonal turnover and water turbulence caused by wind, whereas the influx of nutrients in streams and rivers appears as pulses acquired from the adjacent floodplain normally caused by seasonal rainfall. The outflow of these available organic and inorganic compounds is also different. In lakes, losses are mainly by sedimentation, which makes these resources readily recyclable in a suitable condition. On the other hand, losses in the lotic systems seem to be less recyclable due to the unidirectional flow of water volume [21-24].

In the northern part of Thailand, growths of Cladophora regularly occur along river shorelines. Conspicuous populations in the Nan River, which is one of the main rivers of the northern part of Thailand, are harvested for culinary ("Kai") and medicinal purposes [25-31] and making bioethanol [32]. Even so, the algal microbiome has never been investigated. Therefore, in this study, we used amplicon analyses to study the diversity of microbiota living in Cladophora sp. present along the Nan River. Results showed that the diversity of prokaryotes and eukaryotes in the algal microbiomes significantly differed among study sites. About half of the identifiable taxa were commonly present in all the replicates. These organisms, which include heterotrophic bacteria and decomposers, span multiple trophic levels, which suggests the presence of a complex food chain within the algal microbiome. Additionally, by functional inference, these organisms putatively provide various ecological functions in the Nan River.

\section{Materials and Methods}

Algal samples were collected from Nan River, Nan, Thailand, during the late growing season in March 2020. Five collecting sites with four replicates per site were located in four different districts-Chiang Klang $\left(19^{\circ} 13^{\prime} 34.0^{\prime \prime} \mathrm{N} 100^{\circ} 49^{\prime} 22.8^{\prime \prime} \mathrm{E}\right.$ : defined as

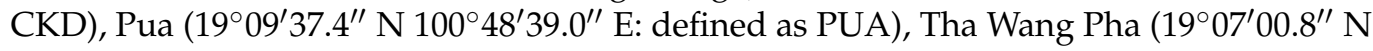
$100^{\circ} 48^{\prime} 11.9^{\prime \prime} \mathrm{E}$ and $19^{\circ} 02^{\prime} 18.8^{\prime \prime} \mathrm{N} 100^{\circ} 46^{\prime} 56.2^{\prime \prime} \mathrm{E}$ : defined as TD1 and TD2, respectively), and Mueang Nan District (18 $58^{\prime} 52.1^{\prime \prime}$ N $100^{\circ} 46^{\prime} 36.3^{\prime \prime}$ E: defined as MND) as shown in Figure 1. The collected algal samples were submerged in DNA/RNA Shield ${ }^{\mathrm{TM}}$ (Zymo Research, Irvine, CA, USA) and stored in sterile microcentrifuge tubes and Whirl-Pak ${ }^{\circledR}$ (Nasco, Madison, WI, USA) before being brought back to the laboratory for the following analysis. Additionally, we obtained the secondary information of the water physical properties from the annual report available at Regional Environmental Office 2 Lampang (http:/ / www.reo02.mnre.go.th/th/index; accessed on 27 August 2021). The information 
included values of the water quality index, dissolved oxygen, biological oxygen demand, and ammonia nitrogen content.

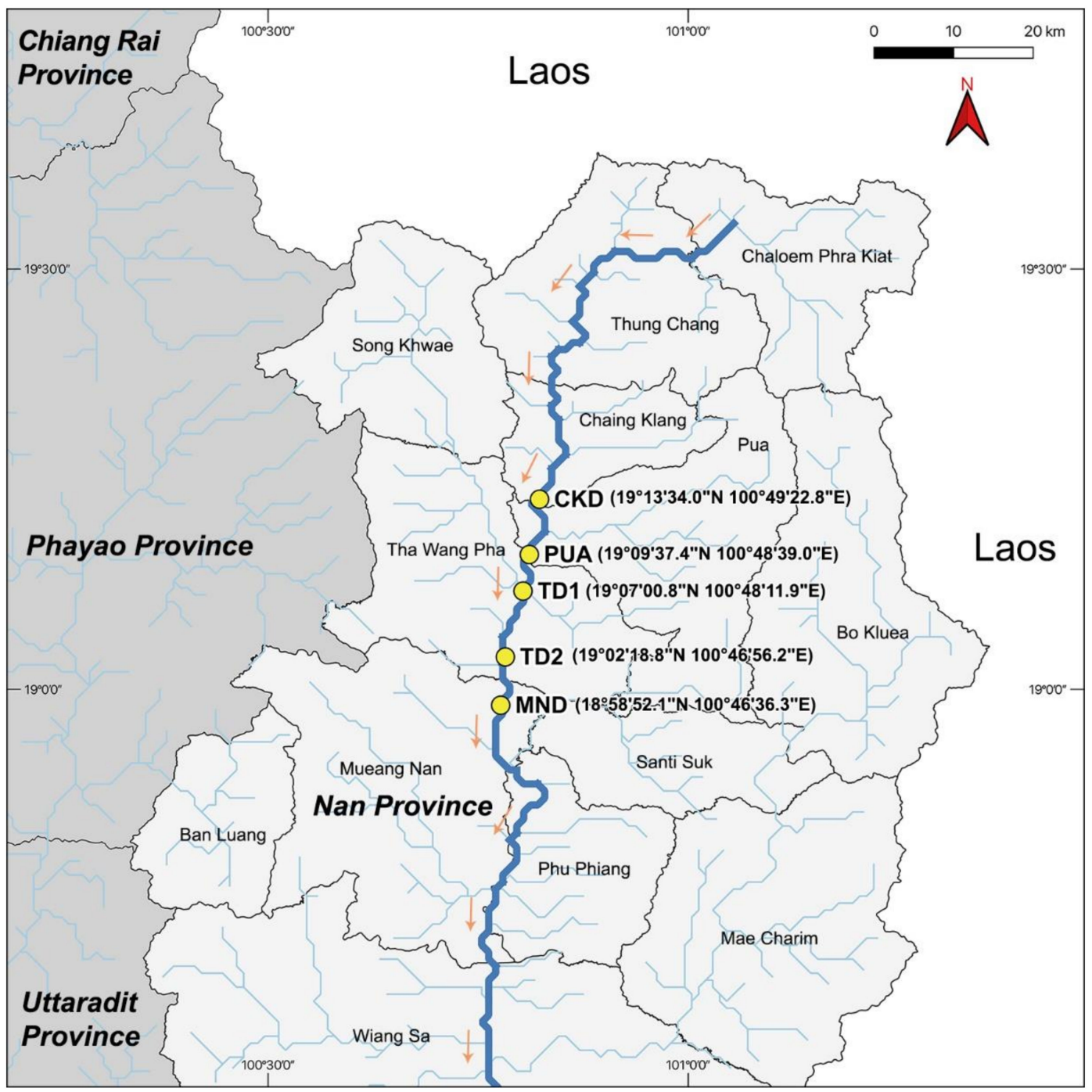

Figure 1. Five sample collecting sites in Nan River, Nan Province, located in four different districts. CKD located in Chiang Klang district, PUA located in Pua district, TD1 and TD2 located in Tha Wang Pha district, and MND located in Mueang Nan district. Only three locations (CKD, PUA, and TD1) were Cladophora dominant. Yellow dot represents each collecting site. Bold blue line represents the Nan River. Orange arrows represent the flow direction. Other blue lines represent other smaller rivers and streams.

\section{Algal Identification}

At the laboratory, the algal samples were put into sterile petri dishes submerged in DNA/RNA Shield ${ }^{\mathrm{TM}}$. Algal filaments were selected using sterile forceps and washed three times to remove loosely associated materials. Then, the alga samples were observed using an ECLIPSE E100 microscope (Nikon Corporation, Tokyo, Japan). Only samples from sites dominated by Cladophora were employed in this study. To select the Cladophora dominant samples, we used morphological characteristics of algal samples to identify the alga to the genus level [33]. To identify the dominant Cladophora species of each replicate, we used the assembled 18S rDNA amplicons to perform BLASTN search against the NCBI non-redundant nucleotide database (accessed on 13 September 2021). 


\section{Taxonomic Identification of Microbial Taxa \\ Light Microscopy}

When possible, microbes associated with filaments of the Cladophora host were identified to genus level using group-specific identification keys [34-37]. The permanent slides of algal specimens, included their replicates, have been deposited as barcode number BCU5004 (CKD), BCU5005 (PUA), and BCU5006 at Kasin Suvatabandhu Herbarium, Department of Botany, Chulalongkorn University, Thailand (https://www.chula.ac.th/ museum/763/).

\section{Taxonomic Informatic Analysis of Amplicons (SSU and ITs)}

\subsection{DNA Extraction and Sequencing}

The Cladophora samples were washed three times using DNA/RNA Shield ${ }^{\mathrm{TM}}$ to remove the dirt and debris. Then, genomic DNA was extracted using Quick-DNA ${ }^{\mathrm{TM}}$ Fecal/Soil Microbe Kits (Zymo Research, Irvine, CA, USA). The 16S rRNA region V3-V4 was amplified using primers $341 \mathrm{~F}$ and $805 \mathrm{R}$ [38], the $18 \mathrm{~S} \mathrm{rRNA}$ region $\mathrm{V} 4$ was amplified using primers Reuk454FWD1 and V4r [39], and the ITS was amplified using primers ITS-1F [40] and ITS-2R [41], as provided in Table S1. The amplicons were then purified, indexed, and sequenced using an Illumina MiSeq at Omics Sciences and Bioinformatics Center (Chulalongkorn University, Bangkok, Thailand).

\subsection{Data Analysis}

The quality of the 250 bp paired-end raw reads was assessed by FastQC [42]. Lowquality nucleotide bases were removed using Trimmomatic v. 0.39 using SLIDINGWINDOW:4:30 [43]. The taxa and the taxonomic diversity of the epiphytic microbiota of Cladophora sp. were identified and assessed by comparing the annotated rDNA against the SILVA ribosomal RNA gene database release 138.1 [44] using SILVAngs pipeline. In the workflow, trimmed reads were aligned using SILVA INcremental Aligner (SINA). Reads shorter than 50 aligned nucleotides, with ambiguities larger than $2 \%$, or with homopolymers larger than $2 \%$ were eliminated before entering the downstream processes. Then, putative contaminant reads, including PCR artifacts and low-quality aligned reads (with alignment identity less than $50 \%$ and alignment score less than 40 ), were filtered out.

Reads that passed the filtered steps were then de-replicated. Identical reads were identified and clustered into different Operational Taxonomic Units (OTUs) using cd-hitest [45] running in accurate mode, overlooking overhangs, and applying identity criteria of 1.00 and 0.98 , respectively. Then for each cluster, the representative sequence was then classified by a local nucleotide BLAST search against the non-redundancy of the SILVA SSU Ref database release 138.1 using BLASTN with standard settings. The classifiable reads were mapped onto all reads that were assigned to the respective OTU. Lastly, to filter out chimeric reads, we searched the classified results against SILVA release 138.1 SSU using VSEARCH v. 2.8.3.0 [46] implemented in Galaxy v. 1.39.5.1 [47]. Then the taxonomic classification was called if the sequence returned BLASTN with a score of "(percentage sequence identity + percentage alignment coverage) $/ 2$ " greater than or equal to 93. Otherwise, the OTUs were called "No relative".

In addition to the SILVAngs pipeline, for detecting fungi, we used a local BLASTN by searching our assembled ITS amplicons against the UNITE database v. 7.2 [48] (sh_refs_qiime _ver7_97_01.12.2017.fasta available at https:// dx.doi.org/10.15156/BIO/587481 (accessed on 16 November 2020) using E-value $=1 \times 10^{-10}$. Then, we filtered out the chimeric reads by using VSEARCH v. 2.8.3.0 [46] implemented in Galaxy v. 1.39.5.1 by searching the obtained reads against the UCHIME reference datasets v. 7.1 [49] (uchime_reference_dataset_01.01.2016.fasta available at https://unite.ut.ee/sh_files/uchime_reference_dataset_01.12.2016.zip (accessed on 19 November 2020).

The raw data for the Cladophora microbiomes have been deposited in NCBI SRA BioProject PRJNA761577 and BioSample SAMN21356006 (CKD), SAMN21356007 (PUA), and SAMN21356008 (TD1). 


\section{Diversity Estimation}

\subsection{Alpha Diversity}

The taxonomic abundance of the microbial taxa was assessed using the results returned from the SILVAngs pipeline. To assess the alpha-diversity, we firstly calculated the values of Shannon index, Simpson index, Chao1, and richness using functions namely diversity and estimateR implemented in the vegan package v. 2.5-7 [50] in RStudio v. 1.4.1106 [51]. To evaluate whether the values obtained from calculations were statistically different, values of One-way ANOVA $(p<0.05)$ and Tukey's HSD were calculated using the agricolae package v. 1.3-5 [52]. Then, results were visualized using box plots implemented in the ggplot2 package v. 3.3.5 [53] in RStudio.

\subsection{Beta Diversity}

Beta-diversity index, Bray-Curtis dissimilarity, was calculated using the vegdist function in the vegan package [50] in RStudio. Then, to examine whether the values of Bray-Curtis dissimilarity were statistically different, we performed Analysis of Similarity (ANOSIM; function anosim, vegan package) and permutational Multivariate Analysis of Variance (perMANOVA; function adonis, vegan package) using 999 permutations. Results were then visualized using the Principal Coordinate Analysis (PCoA) with the cmdscale function.

\section{Common Organisms in Lotic and Lentic Freshwater Cladophora Microbiome}

To investigate the presence of taxa that are commonly present in freshwater Cladophora microbiomes, we re-analyzed the taxonomic classification using the SILVAngs pipeline described above for sequence read archive of metagenomic data from Cladophora collected from Lake Mendota (Madison, WI, USA) [6,9] and Lake Michigan (Portage, IN, USA) [7]. Then, we searched for the taxa commonly present in the lotic and lentic Cladophora microbiomes.

\section{Results}

Identification of Cladophora sp.

Only the algal samples collected from three sites (CKD, PUA, and TD1) were morphologically identified to genus Cladophora, having distinct characteristics of monosiphonous and branched filaments with a unique branching style, where the lateral branch arisen under the septum between two cells of the main axis. Each cell in the filament contained reticulate chloroplasts and thick cell walls (Figure 2A). The algal basal region was attached to the substrates using holdfast. The filaments appeared as tufts, forming the macroscopic green algal bloom floating in water (Figure 2B).

In addition to having similar morphology, the Cladophora samples collected from the three sites also have identical amplicon sequences (Figure S1). BLASTN results suggested that the sequence was equally similar to published and unpublished freshwater Cladophora spp. reported from authors from several countries (Table S2). 

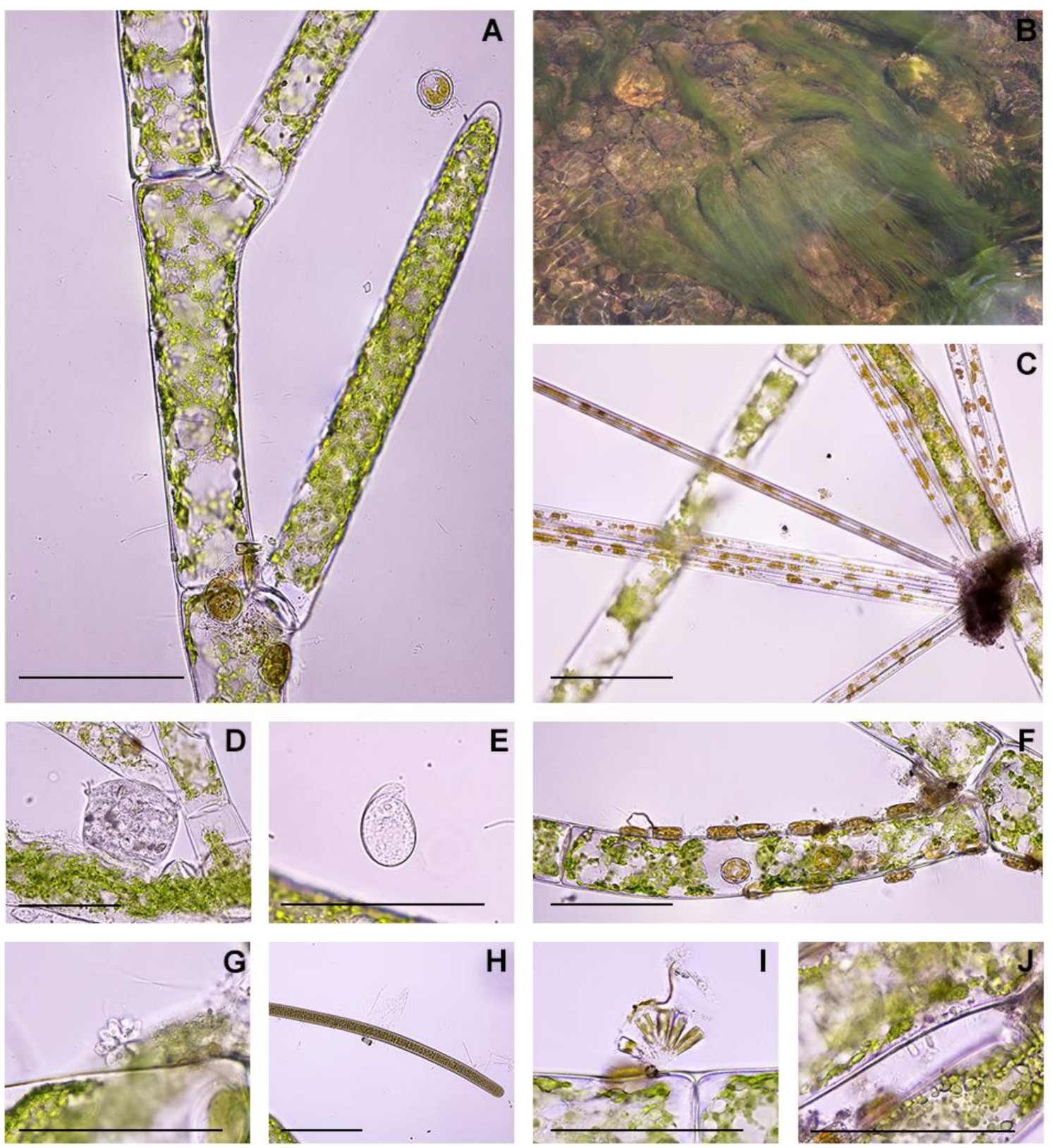

Figure 2. Morphological characteristic of Cladophora sp. collected from Nan River, Thailand, and epiphytic microbes under light microscopy. (A)-Morphology of Cladophora sp., showing branched monosiphonous filament with reticulate chloroplasts. (B)-Macroscopic Cladophora sp. filaments attached to substrate. (C)—Stramenopile Synedra. (D) -Ciliate Vorticella. (E) —other Ciliate. (F)—Stramenopile Cocconeis. (G)—Stramenopile Synura. (H)—Cyanobacterium Oscillatoria. (I) - Stramenopile Gomphonema. (J)_Cyanobacterium Chamaesiphon. Black scale bars: $100 \mu \mathrm{m}$.

\section{Taxonomic Identification of Microbial Taxa}

\subsection{Light Microscopy}

When observed under the light microscope, algal filaments were observed to host a high abundance of the photosynthetic stramenopile (diatom) Cocconeis C.G. Ehrenberg (Figure 2F) and the cyanobacterium Chamaesiphon A. Braun and Grunow (Figure 2J). In addition, photosynthetic stramenopiles Synura C.G. Ehrenberg, Synedra C.G. Ehrenberg, and Gomphonema C.G. Ehrenberg (Figure 2C,G,I), the Vorticella C. Linnaeus and other ciliates (Figure 2D,E), and cyanobacterium Oscillatoria Vaucher ex Gomont (Figure 2H) were always present in association with the alga. 


\subsection{Amplicon Analysis}

\subsubsection{SSU-16S rDNA Amplicon Analysis}

Amplicon analysis showed that bacterial phyla and their relative abundance varied (Figure 3). The five most abundant phyla in site CKD were Proteobacteria $(40.04 \%)$, Bacteroidetes $(21.07 \%)$, Firmicutes $(10.59 \%)$, Verrucomicrobia (5.30\%), and Planctomycetes $(4.80 \%)$. The five most abundant phyla in site PUA were Proteobacteria $(29.29 \%)$, Bacteroidetes $(22.50 \%)$, Firmicutes $(10.86 \%)$, Planctomycetes $(6.88 \%)$, and Cyanobacteria $(6.20 \%)$. The five most abundant phyla in site TD1 were Proteobacteria $(31.77 \%)$, Bacteroidetes $(24.37 \%)$, Firmicutes $(6.67 \%)$, Verrucomicrobia $(6.22 \%)$, and Cyanobacteria $(4.98 \%)$. Bacterial taxa were classified into 689 distinct genera; 227 bacterial genera were present in all four replicates of the three collecting sites (Table S3).

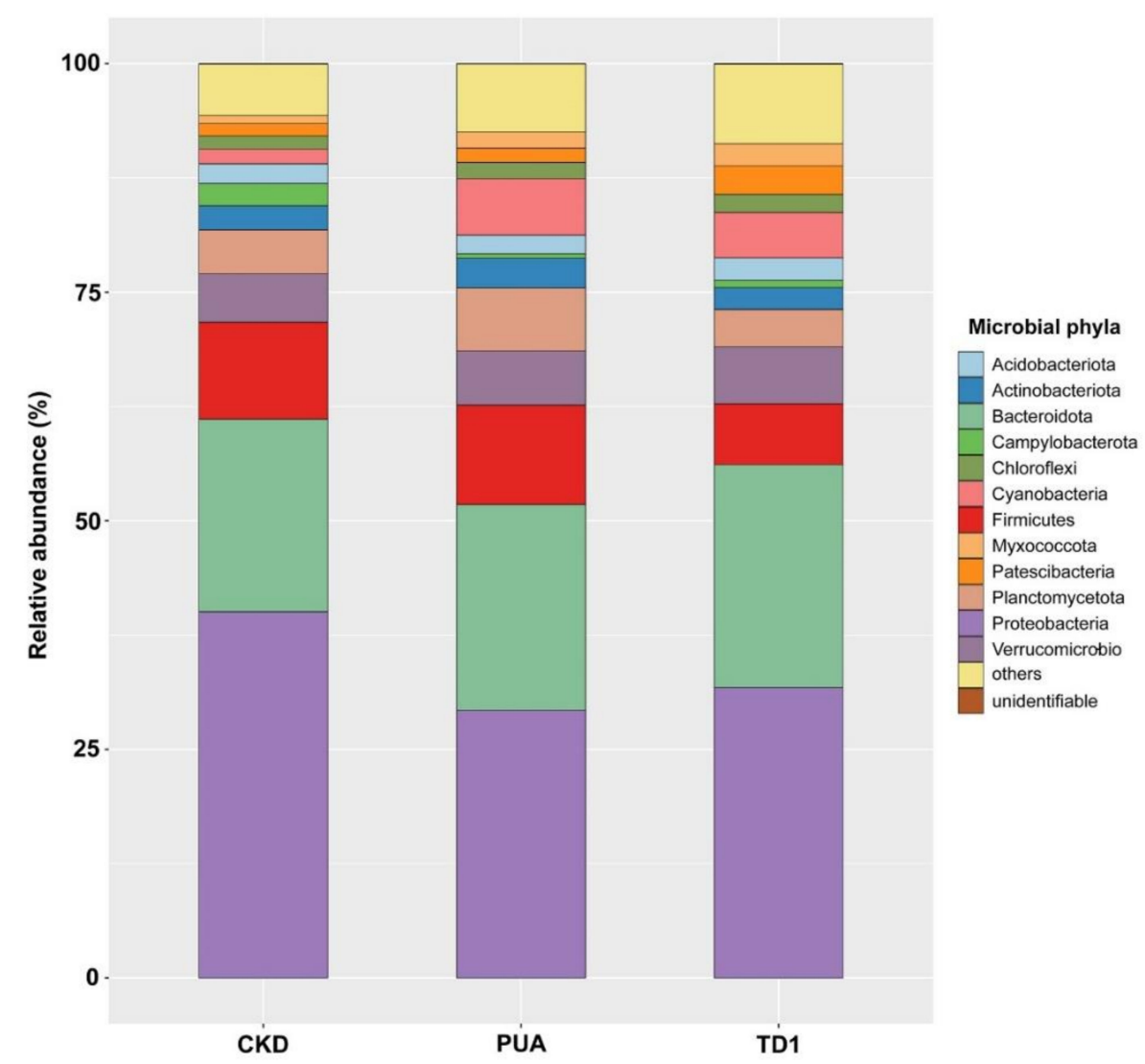

Figure 3. Results from $16 \mathrm{~S}$ rDNA amplicon analysis of Cladophora sp. collected from Nan River, sites CKD, PUA, and TD1, showed that bacterial phyla and their relative abundance varied. The five most abundant phyla in site CKD were Proteobacteria (40.04\%), Bacteroidetes (21.07\%), Firmicutes (10.59\%), Verrucomicrobia (5.30\%), and Planctomycetes (4.80\%). The five most abundant phyla in site PUA were Proteobacteria (29.29\%), Bacteroidetes (22.50\%), Firmicutes (10.86\%), Planctomycetes $(6.88 \%)$, and Cyanobacteria (6.20\%). The five most abundant phyla in site TD1 were Proteobacteria (31.77\%), Bacteroidetes (24.37\%), Firmicutes (6.67\%), Verrucomicrobia (6.22\%), and Cyanobacteria (4.98\%).

The three collected sites in this study were located in the upper region of the Nan River, where the water flowed from CKD to PUA and TD1, respectively. We initially sampled the water from each site for physical and chemical measurements. However, all the assessment facilities were shut down for a few months, which made it not possible to obtain such parameters from the collecting sites. However, we compared the abundance of the common bacterial genera and found that some bacterial genera occurred as a gradient from the upper stream (CKD) to the lower stream of the river (TD1). Genera that had higher relative abundance in the upper stream included Proteobacteria Acinetobacter, Aeromonas, and Vogesella, Epsilonproteobacteria Pseudarcobacter, Firmicutes Clostridium Sensu stricto 
12, and Bacteroidetes Bacteroides and Flavobacterium. In contrast, genera that had higher relative abundance in the lower stream included Bacteroidetes Paludibacter, Proteobacteria Hydrogenophaga and Leptothrix, and Firmicutes Fusibacter (Table S3).

\subsubsection{SSU-18S rDNA Amplicon Analysis}

The supergroups and their relative abundance obtained from $18 \mathrm{~S}$ rDNA amplicon analysis were also varied. These included 575 genera belonging to Alveolata, Amorphea, Archaeplastida, Cryptophyceae, Rhizaria, and Stramenopiles (Table S3). The five supergroups with the highest relative abundance at site CKD were Amorphea (46.19\%), Stramenopiles (27.10\%), Archaeplastida (17.33\%), Rhizaria (5.55\%), and Alveolata (3.66\%). Supergroups for site PUA were Stramenopiles (45.84\%), Amorphea (28.95\%), Archaeplastida $(15.71 \%)$, Rhizaria (5.33\%), and Alveolata (4.01\%). Supergroups for site TD1 were Stramenopiles (46.04\%), Amorphea (27.83\%), Archaeplastida (12.55\%), Rhizaria (7.02\%), and Alveolata (6.37\%) (Figure 4).

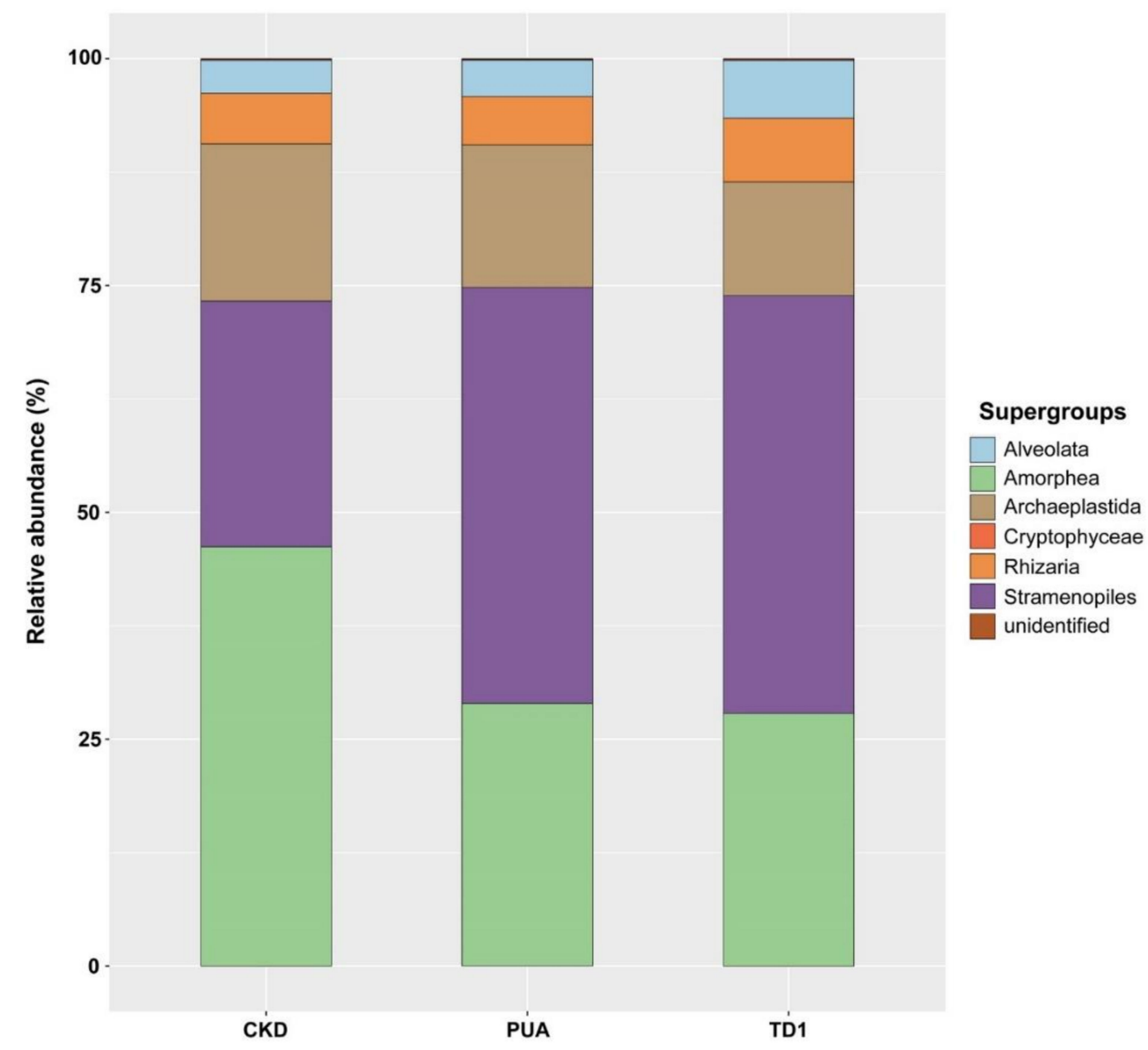

Figure 4. Results from $18 \mathrm{~S}$ rDNA amplicon analysis of Cladophora sp. collected from Nan River, sites CKD, PUA, and TD1, showed that supergroups and their relative abundance were varied. The five supergroups with the highest relative abundance at site CKD were Amorphea (46.19\%), Stramenopiles $(27.10 \%)$, Archaeplastida (17.33\%), Rhizaria (5.55\%), and Alveolata (3.66\%). Supergroups for site PUA were Stramenopiles (45.84\%), Amorphea (28.95\%), Archaeplastida (15.71\%), Rhizaria (5.33\%), and Alveolata (4.01\%). Supergroups for site TD1 were Stramenopiles (46.04\%), Amorphea (27.83\%), Archaeplastida (12.55\%), Rhizaria (7.02\%), and Alveolata (6.37\%).

Among the annotated genera, 51 were present in all sites and some genera exhibited a higher relative abundance. These included Alveolata Trochilia, Amorphea Nuclearia, Paramicrosporidium, and Sorodiplophrys, Archaeplastida Jaoa, Planktosphaeria, Spirogyra, Rhizoclonium, Rhizaria Heteromita, and Stramenopiles Aphanomyces, Cocconeis, Gomphonema, 
Leptolegnia, Ochromonas, Paraphysomonas, Poteriospumella, and Pythium. In addition, genera that were more abundant in the upper stream included Amorphea Paramicrosporidium, Archaeplastida Planktosphaeria, and Stramenopiles Poteriospumella, whereas the genera that were more abundant in the lower stream included Amorphea Nuclearia and Stramenopiles Paraphysomona (Table S4).

\subsection{ITS Amplicon Analysis}

The ITS sequences from only one site (TD1) were successfully amplified and sequenced. Results from taxonomic classification showed that the five most abundant phyla were Ascomycota (53.96\%), Chytridiomycota (29.95\%), Basidiomycota (9.22\%), Rozellomycota $(0.81 \%)$, and Glomeromycota $(0.26 \%)$. The 10 genera with the highest relative abundance were Avachytrium (18.57\%), Entophlyctis (10.95\%), Cladosporium (3.61\%), Capnobotryella (2.54\%), Hannaella (2.40\%), Glutinoglossum (2.33\%), Sporobolomyces (2.29\%), Inocybe (0.96\%), Cryptococcus (0.61\%), and Acremonium (0.38\%) (Table S5).

\section{Diversity Estimation}

\subsection{Alpha Diversity}

Alpha-diversity indices revealed the diversity, evenness, and richness within each study site. Shannon's index indicates the diversity within site, in which richness, evenness, and rare OTUs played an essential role in the measure. Simpson's index indicates diversity as Shannon's index does, however, the rare OTUs play a minor role in the estimation. Chao1 and the number of identifiable OTUs reflect the richness within site.

For the bacterial taxa, at the phylum level (Figure 5A), Shannon's indices showed that PUA (2.24) and TD1 (2.23) were statistically more diverse than CKD (2.00) as $p<0.001$. Simpson's indices of PUA (0.83) and TD1 (0.82) were also statistically more diverse than CKD (0.77) as $p<0.005$. Chao1 of CKD, PUA, and TD1 were 31.19, 35.53, and 36.58, where only the Chao1 of TD1 was statistically higher than CKD $(p<0.01)$. The richness or number of identifiable bacterial phyla of CKD, PUA, and TD1 were 31.00, 35.50, and 36.50, respectively, where the richness values of PUA and TD1 were statistically higher than that of CKD $(p<0.01)$.

At the genus level of the bacterial taxa (Figure 5-B), Shannon's indices of CKD, PUA, and TD1 were 4.91, 5.11, and 5.12, which were not statistically different. Simpson's index of the three sites was 0.98. Choa1 of CKD, PUA, and TD1 were 488, 491, and 496, respectively, which were not statistically different. The richness values of CKD, PUA, and TD1 were 461, 474, and 470, respectively, which also were not significantly different.

For eukaryotes, at the genus level (Figure 5C), Shannon's index of CKD, PUA, and TD1 were $4.34,3.23$, and 3.71, where the diversity of CKD was statistically more diverse than PUA $(p<0.01)$. Simpson's index of CKD (0.96) and TD1 (0.90) were statistically more diverse than PUA (0.8) at $p<0.001$. Choa1 of CKD, PUA, and TD1 were 290, 210, and 264, which were not significantly different. The richness of CKD, PUA, and TD1 were 263, 190, 237, which were also not significantly different. 

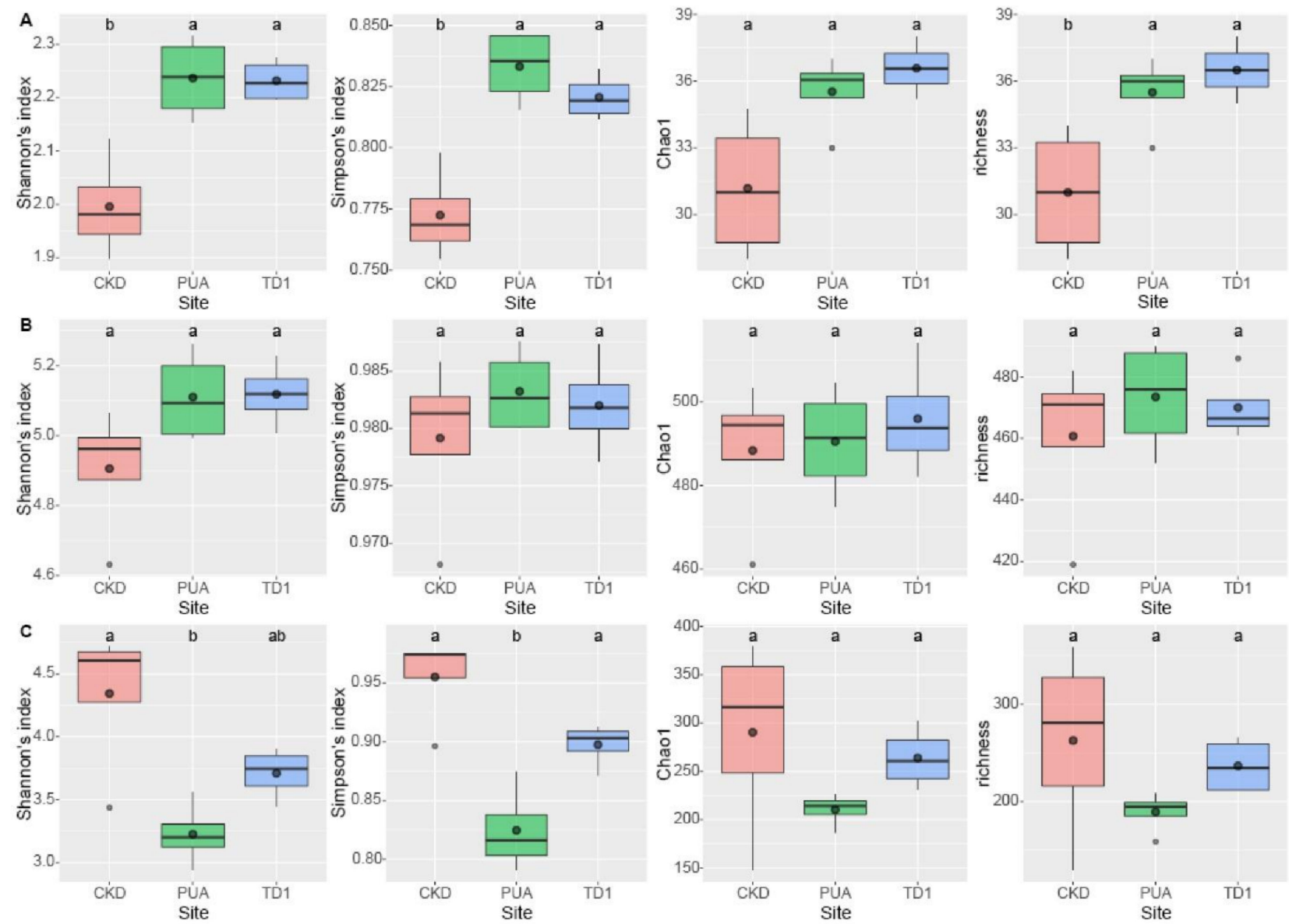

Figure 5. Boxplots of Alpha-diversity indices included Shannon's index, Simpson's index, Chao1, and richness (number of identifiable taxa) of Cladophora microbiomes collected from Nan River, Thailand. (A) Bacterial phyla. (B) Bacterial genera. (C) Eukaryotic genera. Different lowercase letters indicated statistically significant differences using Tukey's HSD at a significant level of $p<0.05$.

\subsection{Beta Diversity}

Comparative analysis showed that the Bray-Curtis dissimilarity values of the bacterial phyla were not different among sites while the bacterial genera from the three study sites were significantly different from each other. The $\mathrm{R}$ value, which signifies dissimilarity between groups based on the Bray-Curtis dissimilarity values, resulted from both ANOSIM and permANOVA was $0.852(p<0.001)$. PCoA based on Bray-Curtis dissimilarity showed that the variance explained of PCo1 and $\mathrm{PCo} 2$ were $45.31 \%$ and $22.42 \%(67.73 \%$ in total), where the PCoA plot showed the prominent cluster of each site, representing the similarity of bacterial genera within each site (Figure 6A).

For eukaryotes, at the genus level, the R value obtained from both ANOSIM and permANOVA was $0.630(p<0.001)$. Results from PCoA based on Bray-Curtis dissimilarity showed that the variance explained of PCo1 and PCo2 were $47.86 \%$ and $22.17 \%(70.03 \%$ in total), where the PCoA plot showed a cluster of PUA and TD1 that distinguished these sites from CKD (Figure 6B). 

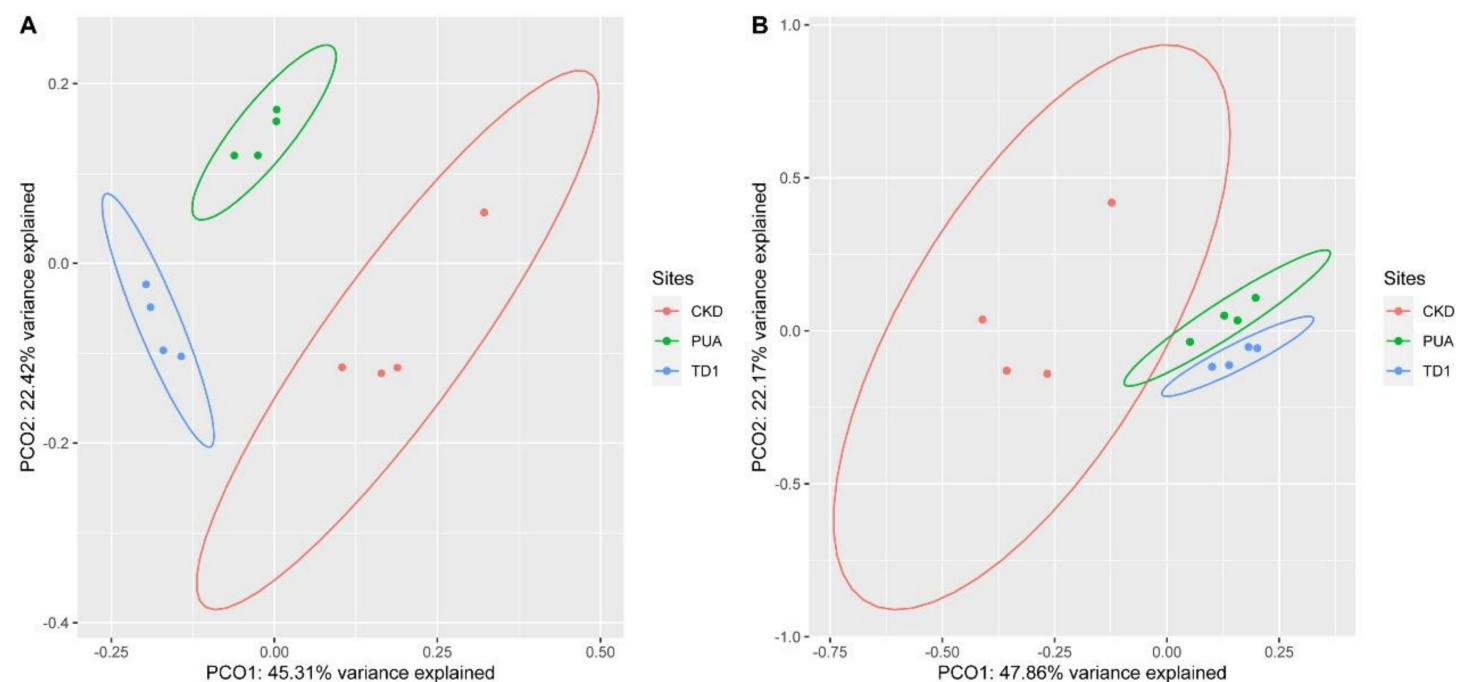

Figure 6. Principal Coordinate Analysis (PCoA) based on Bray-Curtis dissimilarity of Cladophora microbiomes collected from Nan River, Thailand. (A) Bacterial genera. (B) Eukaryotic genera.

\section{Common Members of Freshwater Cladophora Microbiomes}

The wide distribution range of the freshwater Cladophora sp. made it interesting to investigate whether the alga present in different geographical areas and different ecosystems (lotic and lentic) host a common group of microbes. Therefore, we compared the microbiomes of Cladophora found in this study to those of previously reported studies. Results showed that among the reports of Cladophora microbiomes, the Cladophora microbiome shared more common taxa with results reported from Lake Mendota, USA $[6,9]$ than to Lake Michigan [7]. Interestingly, though different in abundance, 17 bacterial genera were present in microbiomes of all these freshwater Cladophora studies. These included Bacteroidetes Chryseobacterium, Flavobacterium, Terrimonas, Deinococcus-Thermus Deinococcus, Proteobacteria Acidovorax, Acinetobacter, Altererythrobacter, Aquabacterium, Bdellovibrio, Hydrogenophaga, Hyphomicrobium, Methylotenera, Novosphingobium, Pseudomonas, Pseudorhodobacter, Rhodobacter, and Sphingopyxis (Table S6).

\section{Discussion}

Along the river basin, Cladophora appeared as tufts/thalli attached on the rock surface across the river streams where the water level was about knee height. Among the collecting sites, Cladophora dominated the upper regions of the Nan River (CKD, PUA, and TD1), where the water temperatures were lower and the main substrates were rocks and pebbles.

Presence of similar algal morphology and identical sequences of selected gene markers suggested that the algal samples collected in this study belong to the same algal population. The best 100 BLASTN results of Cladophora amplicons in this study were sequences from published and unpublished Cladophora species collected from different countries, showing the same total score, percent identity, and E-value (Table S2). This suggested that the amplified region had been conserved across different Cladophora populations. We, therefore, could not annotate the algal sample further than the genus level.

It was interesting to us that although we found that our amplicons were identical to sequences reported from other locales, these amplicons were not identical to any of the reported freshwater Cladophora found in Thailand or the neighboring counties, e.g., GenBank accession LT607372.1 [54] and accessions JQ071987.1-JQ072004.1 [55]. This suggests that there might be more than one population of the freshwater Cladophora endemic to the region, which has not yet been explored. 


\section{Microbiomes of Lentic Cladophora sp.}

The nature of Cladophora, producing high-surface-area filaments attached to substrates in the river basin, makes it crucial in the ecosystem by providing microhabitats for other microbial organisms. Results from amplicon analysis revealed that the dominant epiphytic eukaryotes in the three sampling sites were Amorphea and Stramenopiles, which agreed with results from light microscopy, where we observed zooplankton and photosynthetic stramenopiles Cocconeis, Gomphonema, Synura, Synedra, and Navicula on the Cladophora cell surface.

Among the diatoms, Cocconeis and Gomphonema were present in all the sampling replicates, judged by both microscopic and molecular evidence, where the relative abundance of Cocconeis ranged from $4.9 \%$ at CKD to $27.4 \%$ at PUA, and the relative abundance of Gomphonema ranged from $4.6 \%$ at TD1 to $0.8 \%$ at PUA. The presence of dominant Cocconeis and Gomphonema on the filament surface was similar to results from previous studies $[9,10]$, which hypothesized that this diatom's cell shape allowed it to avoid grazing and maintain firm attachment to the algal filament.

In addition to the dominant diatom Cocconeis, a few other diatoms were also present in all the sampling sites, e.g., Achnanthidium, Amphora, Craticula, Cymbella, Epithemia, Fistulifera, Gomphonema, Melosira, Navicula, Nitzschia, Pinnularia, Planothidium, Rhopalodia, and Thalassiosira. These diverse diatoms on the algal filaments might be explained by ability to tolerate shading that occurs in the Cladophora tuft. Within the algal tuft, the high density of algal filaments results in variation in light intensity. By having such ability, the diatoms can maintain their abundance by upregulating the expression of genes involved in transcription and photosynthesis to compensate for the lower light intensity [56].

Presence of these diatoms on the Cladophora surface promotes high diversity of the algal microbiome as these diatoms release their photosynthetic exudates or exopolysaccharides, which provide the building blocks of biofilms that encase the algal filaments, e.g., $[57,58]$. According to results from our amplicon analysis, there were 698 unique bacterial genera and 575 unique eukaryotic genera present in the Cladophora microbiome (Tables S3 and S4).

Alpha indices suggested that the diversity of bacterial phyla at PUA and TDI was higher than that of CKD, whereas the eukaryotic genera were more diverse at CKD than at PUA and TD1. In addition, clusters obtained from the PCoA plots suggested that the diversity of the eukaryotic genera and the bacterial genera was more similar within site than among sites. It is unclear at this stage why the diversity of these microbiomes was statistically different. However, we believe that it is not mainly affected by the trophic states of the water at the collecting site as the trophic states do not correlate with the diversity level of the organisms [59-61]. In this study, although we failed to collect the physical properties of the water from the sampling sites, secondary data obtained from the annual report of the local environmental organization showed that the trophic state of the water in the Nan River fluctuated. The values of water quality index, dissolved oxygen, biological oxygen demand, and ammonia nitrogen content appeared to fluctuate along the course of the river (Figure S2). To understand this better, an investigation of the biomes presents at the riverbank or the adjacent floodplains might be needed. Variation in effluent inputs to the river might also be important.

Although our results showed different bacterial diversity along the river course, we found a total of 227 identifiable bacterial genera that were commonly present in all sites that might be involved in various important ecological functions (Table 1). Among these common genera, some appeared to be more abundant when compared to other common genera across the three study sites. These included taxa involved in processes like cellulose degradation (Bacteroides and Paludibacter), cobalamin (vitamin $\mathrm{B}_{12}$ ) biosynthesis (Flavobacterium), fermentative hydrogen production (Acetobacteroides and Clostridium sensu stricto 12), ammonium oxidation (Pirellula), amino acid fermentation (Acidaminobacter), dissimilatory reduction of nitrate to ammonium (Pelosinus, Aeromonas, and Lacunisphaera), nitrite reduction (Dechloromonas), nitrate reduction (Vogesella), sulfur reduction (Fusibacter), 
polyphosphate accumulation (Acinetobacter and Propionivibrio), denitrifying phosphorusaccumulation (Dechloromonas), degradation of aromatic compounds (Hydrogenophaga), anaerobic chemoheterotroph (Fimbriiglobus), and bacteria with no known specific ecological function, e.g., Emticicia, Pseudarcobacter, and WCHB1-32.

Table 1. Putative ecological functions inferred for bacterial genera commonly present in the Cladophora microbiomes collected from CKD, PUA, and TD1.

\begin{tabular}{|c|c|}
\hline Ecological Functions & Bacterial Genera \\
\hline \multicolumn{2}{|c|}{ Nitrogen cycling } \\
\hline Denitrification & $\begin{array}{c}\text { Acidovorax [62] } \\
\text { Arenimonas [63] } \\
\text { Chromobacterium [64] } \\
\text { CL500-29 marine group [65] } \\
\text { Comamonas [66] } \\
\text { Devosia [67] } \\
\text { Hyphomicrobium [68] } \\
\text { Leptothrix [63] } \\
\text { Methylotenera [69] } \\
\text { OLB13 [70] } \\
\text { Opitutus [67] } \\
\text { Paracoccus [63] } \\
\text { Pseudomonas [67] } \\
\text { Rhodobacter [67] } \\
\text { SM1A02 [71] } \\
\text { Thauera [72] }\end{array}$ \\
\hline Denitrifying phosphorus-accumulation & $\begin{array}{c}\text { Candidatus Accumulibacter [73] } \\
\text { Dechloromonas [73] }\end{array}$ \\
\hline Dissimilatory reduction of nitrate to ammonium & $\begin{array}{c}\text { Aeromonas [74] } \\
\text { Geobacter [74] } \\
\text { Lacunisphaera [74] } \\
\text { Pelosinus [75] }\end{array}$ \\
\hline Ammonium oxidation & $\begin{array}{c}\text { Blastopirellula [76] } \\
\text { Brevifollis [77] } \\
\text { Ellin6067 [78] } \\
\text { Gemmata [79] } \\
\text { mle1-7 [78] } \\
\text { oc32 [78] } \\
\text { Pirellula [79] }\end{array}$ \\
\hline Nitrate reduction & $\begin{array}{c}\text { Noviherbaspirillum [80] } \\
\text { Rhizobacter [81] } \\
\text { Sulfurospirillum [82] } \\
\text { Thauera [82] } \\
\text { Vogesella [83] }\end{array}$ \\
\hline Nitrite oxidation & Candidatus Nitrotoga [84] \\
\hline Nitrite reduction & $\begin{array}{c}\text { Arenimonas [73] } \\
\text { Azoarcus [73] } \\
\text { Dechloromonas [85] } \\
\text { Haliangium [85] } \\
\text { Rhodoferax [86] } \\
\text { Sulfuritalea [85] }\end{array}$ \\
\hline
\end{tabular}


Table 1. Cont.

\begin{tabular}{|c|c|}
\hline Ecological Functions & Bacterial Genera \\
\hline Nitrogen fixation & $\begin{array}{c}\text { Anaeromyxobacter [87] } \\
\text { Azospira [88] } \\
\text { Dechloromonas [89] } \\
\text { Devosia [90] } \\
\text { Mesorhizobium [91] } \\
\text { Methylocystis [92] } \\
\text { Nordella [93] } \\
\text { Pelomonas [94] } \\
\text { Rhizobium [95] } \\
\text { Shinella [96] }\end{array}$ \\
\hline Nitrous oxide reduction & Gemmatimonas [97] \\
\hline \multicolumn{2}{|c|}{ Iron cycling } \\
\hline Fe (II) oxidation & $\begin{array}{c}\text { Curvibacter [98] } \\
\text { Leptothrix [99] } \\
\text { Noviherbaspirillum [80] } \\
\text { Sideroxydans [100] } \\
\text { Undibacterium [98] }\end{array}$ \\
\hline Fe (III) reduction & $\begin{array}{c}\text { Acidibacter [101] } \\
\text { Geobacter [99] } \\
\text { Rhodoferax [99] }\end{array}$ \\
\hline \multicolumn{2}{|c|}{ Manganese cycling } \\
\hline Mn (II) oxidation & $\begin{array}{l}\text { Pedomicrobium [102] } \\
\text { Sideroxydans [100] }\end{array}$ \\
\hline $\mathrm{Mn}(\mathrm{IV})$ reduction & $\begin{array}{c}\text { Geobacter [99] } \\
\text { Rhodoferax [99] }\end{array}$ \\
\hline \multicolumn{2}{|c|}{ Phosphorous cycling } \\
\hline Polyphosphate accumulation & $\begin{array}{c}\text { Acinetobacter [103] } \\
\text { Arcicella [104] } \\
\text { Limnohabitans [104] } \\
\text { Propionivibrio [105] }\end{array}$ \\
\hline \multicolumn{2}{|c|}{ Sulfur cycling } \\
\hline Sulfate reduction & $\begin{array}{c}\text { Desulfobulbus [106] } \\
\text { Desulfomicrobium [107] } \\
\text { Desulfovibrio [108] }\end{array}$ \\
\hline Sulfur oxidation & $\begin{array}{l}\text { Limnobacter [109] } \\
\text { Meiothermus [110] }\end{array}$ \\
\hline Sulfur reduction & Fusibacter [111] \\
\hline \multicolumn{2}{|c|}{ Uranium cycling } \\
\hline $\mathrm{U}(\mathrm{IV})$ reduction & $\begin{array}{c}\text { Anaeromyxobacter [112] } \\
\text { Geobacter [112] }\end{array}$ \\
\hline \multicolumn{2}{|c|}{ Degradation } \\
\hline Alkane degradation & $\begin{array}{c}\text { Aquabacterium [113] } \\
\text { Tropicimonas [114] }\end{array}$ \\
\hline
\end{tabular}


Table 1. Cont.

\begin{tabular}{|c|c|}
\hline Ecological Functions & Bacterial Genera \\
\hline Cellulose degradation & $\begin{array}{c}\text { Aquitalea [115] } \\
\text { Bacteroides [116] } \\
\text { Caulobacter [117] } \\
\text { Cellvibrio [118] } \\
\text { Cloacibacterium [119] } \\
\text { Cytophaga [120] } \\
\text { Exiguobacterium [119] } \\
\text { Ilumatobacter [121] } \\
\text { Paludibacter [119] } \\
\text { Roseimarinus [122] } \\
\text { Ruminiclostridium [123] }\end{array}$ \\
\hline Chitin degradation & $\begin{array}{l}\text { Chitinibacter [124] } \\
\text { Chitinimonas [125] } \\
\text { Massilia [126] } \\
\text { SH-PL14 [127] }\end{array}$ \\
\hline Degradation of aromatic compounds & $\begin{array}{c}\text { Acinetobacter [128] } \\
\text { Azoarcus [99] } \\
\text { Hydrogenophaga [129] } \\
\text { Hyphomicrobium [130] } \\
\text { Leptothrix [99] } \\
\text { Limnobacter [128] } \\
\text { Methylibium [131] } \\
\text { Ottowia [130] } \\
\text { Pseudomonas [128] } \\
\text { Sulfuritalea [130] } \\
\text { Thauera [132] }\end{array}$ \\
\hline Degradation of biodegradable plastics & Sphingopyxis [133] \\
\hline Volatile fatty acid degradation & Ohtaekwangia [134] \\
\hline Other organic pollutant degradation & Rheinheimera [135] \\
\hline \multicolumn{2}{|c|}{ Vitamin biosynthesis } \\
\hline Cobalamin (vitamin $\mathrm{B}_{12}$ ) biosynthesis & $\begin{array}{c}\text { Bacillus [136] } \\
\text { Candidatus Udaeobacter [137] } \\
\text { Flavobacterium [138] } \\
\text { Mycobacterium [70] } \\
\text { Porphyrobacter [139] } \\
\text { Porphyromonas [140] } \\
\text { Pseudomonas [141] }\end{array}$ \\
\hline \multicolumn{2}{|c|}{ Phototrophy } \\
\hline Cyanobacterial phototrophy & $\begin{array}{c}\text { Chamaesiphon [142] } \\
\text { Cyanobium [143] }\end{array}$ \\
\hline Bacterial phototrophy & Chloroflexus [144] \\
\hline Anoxygenic phototrophy & $\begin{array}{c}\text { NOR5/OM60 clade [145] } \\
\text { Rhodobacter [146] } \\
\text { Rhodoferax [147] } \\
\text { Tabrizicola [148] }\end{array}$ \\
\hline Photoheterotrophy & Rubrivivax [149] \\
\hline
\end{tabular}


Table 1. Cont.

\begin{tabular}{|c|c|}
\hline Ecological Functions & Bacterial Genera \\
\hline \multicolumn{2}{|c|}{ Chemotrophy } \\
\hline Aerobic chemoheterotrophy & $\begin{array}{c}\text { Armatimonas [150] } \\
\text { Fimbriiglobus [151] } \\
\text { Flavisolibacter [152] } \\
\text { Hirschia [153] } \\
\text { Lewinella [154] } \\
\text { Phaeodactylibacter [155] }\end{array}$ \\
\hline Aerobic chemoorganotrophy & $\begin{array}{c}\text { Ahniella [156] } \\
\text { Albidovulum [157] } \\
\text { Bryobacter [158] } \\
\text { Chryseobacterium [159] } \\
\text { Haloferula [160] } \\
\text { Hyphomonas [161] } \\
\text { Ideonella [162] } \\
\text { Larkinella [163] } \\
\text { Lysobacter [164] } \\
\text { Novosphingobium [165] } \\
\text { Polaromonas [166] } \\
\text { Runella [167] } \\
\text { Stenotrophobacter [168] } \\
\text { Truepera [169] } \\
\text { Zavarzinella [170] }\end{array}$ \\
\hline Anaerobic chemoorganotrophy & $\begin{array}{c}\text { Anaeromusa and Anaeroarcus [171] } \\
\text { Phascolarctobacterium [172] } \\
\text { Saccharofermentans [173] } \\
\text { Sporomusa [174] }\end{array}$ \\
\hline Carbohydrate fermentation & $\begin{array}{c}\text { Alistipes [175] } \\
\text { Ferruginibacter [176] } \\
\text { Prevotella 9 [177] } \\
\text { Treponema [178] } \\
\text { Vallitalea [179] }\end{array}$ \\
\hline Animo acid fermentation & $\begin{array}{c}\text { Anaerovorax }[180] \\
\text { Acidaminobacter }[181]\end{array}$ \\
\hline Fermentative hydrogen production & $\begin{array}{c}\text { Acetobacteroides [182] } \\
\text { Clostridium sensu stricto } 1 \text { [183] } \\
\text { Clostridium sensu stricto } 12 \text { [184] } \\
\text { Cytophaga xylanolytica [185] }\end{array}$ \\
\hline \multicolumn{2}{|c|}{ Other } \\
\hline Antifungal effect & Duganella [186] \\
\hline Predator & $\begin{array}{c}\text { Bdellovibrio [187] } \\
\text { Herpetosiphon [188] }\end{array}$ \\
\hline Methane oxidation & $\begin{array}{c}\text { Methylocystis [92] } \\
\text { Methylovulum [189] }\end{array}$ \\
\hline Methylotrophy & $\begin{array}{l}\text { Gemmobacter [190] } \\
\text { OM43 clade [191] }\end{array}$ \\
\hline Extracellular polymeric substance (EPS) secretion & Terrimonas [192] \\
\hline Biosorption of heavy metals & Sphaerotilus [193] \\
\hline
\end{tabular}

The majority of the fungi present within the samples collected from TD1 were fungi that function in decomposition, e.g., Avachytrium, Entophlyctis, Glutinoglossum. Other fungi were those known to be involved in (1) parasitism in algae, amoebae, and other fungi, (2) plant-fungal interaction, (3) predation, and even (4) mutualism as in the lichen-forming 
fungi (Table 2). We believe that, while some fungi were present temporarily (e.g., lichenforming fungus, phylloplane fungi, and plant pathogens), a portion of these fungi live within the host algal microbiome. However, to know which fungi live in the associations and which fungi are there temporarily due to the influx from the nearby flood plain, more replications of Cladophora microbiomes from more study sites are needed.

Table 2. Fungal genera commonly present in the Cladophora microbiomes and their putative ecological functions.

\begin{tabular}{|c|c|}
\hline Ecological Functions & Fungal Genera \\
\hline \multicolumn{2}{|c|}{ Decomposing fungi } \\
\hline Saprotrophy & 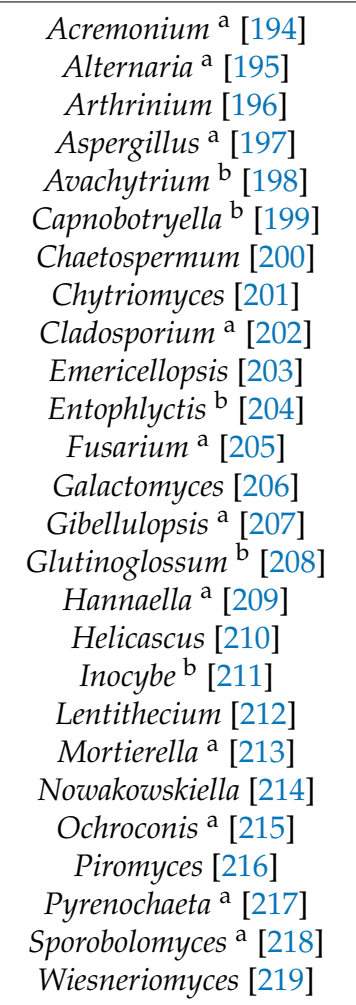 \\
\hline \multicolumn{2}{|c|}{ Parasitism } \\
\hline Endoparasitic chytrid & Rozella [220] \\
\hline Hyperparasites on other fungi & Cladosporium $^{\text {a }}$ [202] \\
\hline Parasites of algae & $\begin{array}{c}\text { Entophlyctis }{ }^{\mathrm{b}} \text { [221] } \\
\text { Phlyctochytrium [222] } \\
\text { Rhizophydium [223] }\end{array}$ \\
\hline Parasites of amoebae & $\begin{array}{c}\text { Acaulopage [224] } \\
\text { Cochlonema [224] } \\
\text { Paramicrosporidium [220] }\end{array}$ \\
\hline Parasitoids of algae & $\begin{array}{c}\text { Aphelidium [225] } \\
\text { Paraphelidium [226] }\end{array}$ \\
\hline \multicolumn{2}{|c|}{ Plant-fungal interaction } \\
\hline Ectomycorrhizal fungi & Inocybe ${ }^{\mathrm{b}}[211]$ \\
\hline Endophytic fungi & $\begin{array}{l}\text { Acremonium }^{\text {a }}[211] \\
\text { Alternaria }^{\text {a }}[195] \\
\text { Arthrinium }^{[196]} \\
\text { Cladosporium }^{\text {a }}[202]\end{array}$ \\
\hline
\end{tabular}


Table 2. Cont.

\begin{tabular}{|c|c|}
\hline Ecological Functions & Fungal Genera \\
\hline Phylloplane fungi & $\begin{array}{c}\text { Cladosporium }^{\text {a }} \text { [202] } \\
\text { Geotrichum }^{[227]} \\
\text { Hannaella }^{\text {a }}[209] \\
\text { Occultifur a }[228] \\
\text { Pichia [229] } \\
\text { Rhodotorula }^{\text {a }} \text { [230] } \\
\text { Sporobolomyces a }{ }^{[229]} \\
\text { Vishniacozyma }^{\text {a }}[230]\end{array}$ \\
\hline Plant growth-promoting fungi & Mortierella a [231] \\
\hline Plant pathogen & $\begin{array}{l}\text { Alternaria }^{\text {a }} \text { [195] } \\
\text { Arthrinium }^{[196]} \\
\text { Cladosporium }^{\text {a }} \text { [202] } \\
\text { Fusarium }^{\text {a }} \text { [232] } \\
\text { Gibellulopsis }^{\text {a }} \text { [207] } \\
\text { Sporisorium }^{\text {a }} \text { [233] }\end{array}$ \\
\hline \multicolumn{2}{|c|}{ Predation } \\
\hline Amoebophagous fungi & Stylopage [234] \\
\hline Nematophagous fungi & Stylopage [235] \\
\hline \multicolumn{2}{|c|}{ Mutualism } \\
\hline Lichen-forming fungi & Capnobotryella ${ }^{\mathrm{b}}$ [198] \\
\hline
\end{tabular}

a Found in both $18 \mathrm{~S}$ rDNA and ITS amplicon analysis. ${ }^{\mathrm{b}}$ Found in ITS amplicon analysis only.

\section{Common Members of Freshwater Cladophora Microbiomes}

We re-analyzed the published data in archives $[6,7,9]$ and investigated if there are shared taxon between the lotic and lentic freshwater Cladophora. As expected, only a few taxa were commonly present in all algal microbiomes as the collecting sites were located in different hemispheres and hydrological systems. All the common taxa were bacteria, which were known to be involved in important ecological activities, including cobalamin (vitamin $\mathrm{B}_{12}$ ) biosynthesis (Flavobacterium and Pseudomonas), extracellular polymeric substance secretion (Terrimonas), aerobic chemoorganotrophy (Chryseobacterium and Novosphingobium), anoxygenic phototrophy (Rhodobacter), polyphosphate accumulation (Acinetobacter), denitrification (Acidovorax and Methylotenera), degradation of alkane (Aquabacterium and Hyphomicrobium), and aromatic compounds (Hydrogenophaga). The presence of these common bacteria might be due to their crucial roles for Cladophora dispersal and survival or the wide distribution of the bacteria themselves. To answer the question, a further investigation of their interactions is needed.

It is challenging to infer interactions between organisms living in the lotic environment as there is an influx and efflux of nutrients occurring continuously. This turbulence affects the richness and abundance of the organisms living in the algal microbiomes, e.g., [236-238]. Even so, data from this study revealed that Cladophora microbiomes were dominated by heterotrophic bacteria (32.57-37.17\%), followed by photoautotrophs $(8.20-14.68 \%)$, micrograzers $(2.48-5.13 \%)$, parasites $(1.52-2.38 \%)$, decomposing fungi $(0.51-1.97 \%)$, and mesograzers $(0.18-0.46 \%)$, as shown in Figure 7 . The presence of similar relative abundances of organisms belonging to different trophic levels and decomposers suggested that there might be some unique interactions or activities present in the lotic freshwater Cladophora microbiomes that have not yet been investigated. 


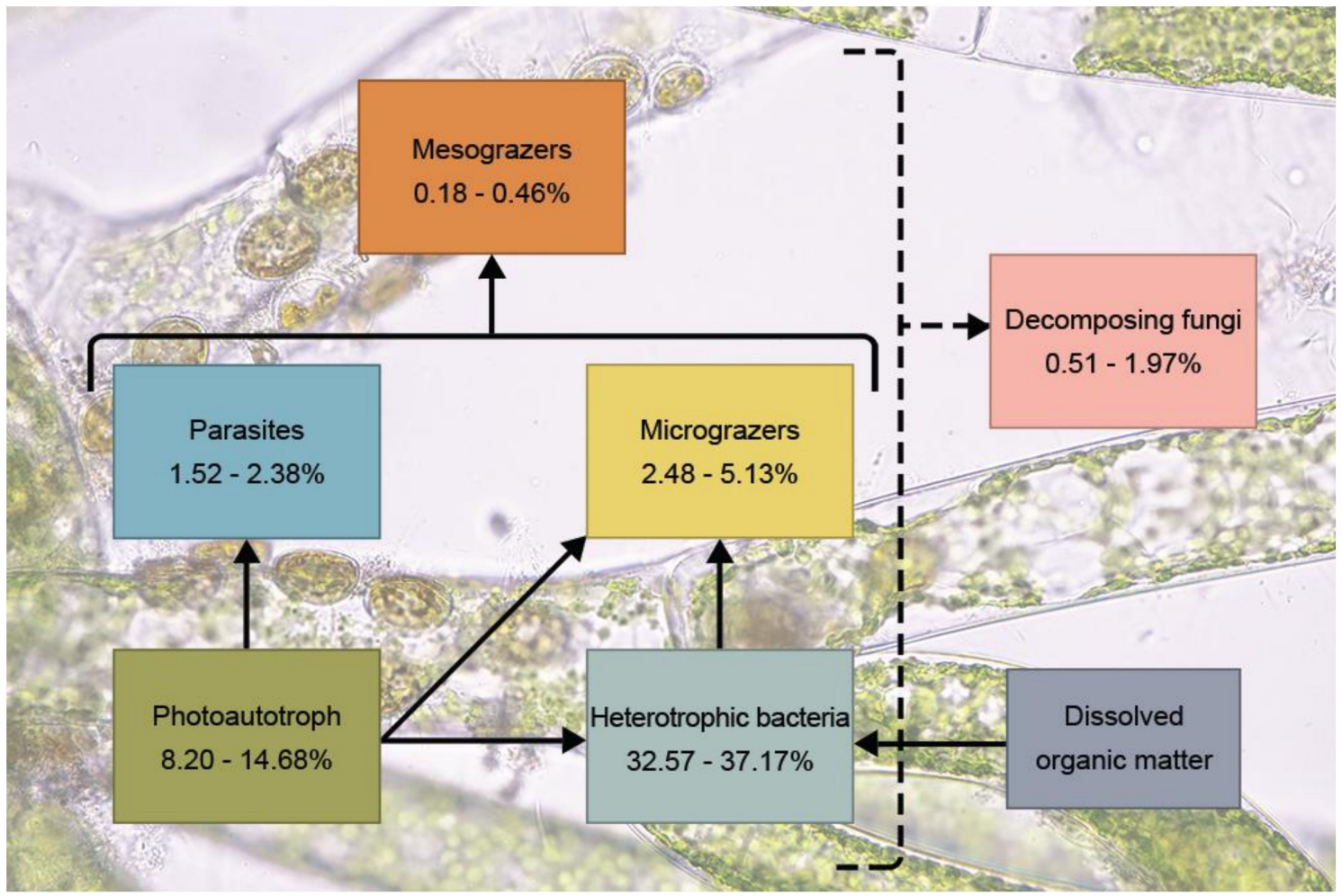

Figure 7. Average of the abundance of organisms living in the Cladophora microbiomes within each collecting site. For the identifiable taxa, the microbiomes were dominated by the heterotrophic bacteria, followed by photoautotrophs, micrograzers, parasites, decomposing fungi, and mesograzers.

In summary, we have shown that the Cladophora sp. that we sampled at three sites along the Nan River belongs to the same algal species. Our amplicon analyses revealed that this alga harbored diverse groups of microorganisms whose taxonomic richness and abundance varied among the sampled sites. About 50 percent of the identifiable taxa were shared among the Cladophora microbiomes. These organisms span different trophic levels in the food chain and putatively serve various ecological services.

Supplementary Materials: The followings are available online at https:/ / www.mdpi.com/article/ 10.3390/plants10112266/s1, Figure S1: Alignment of 18S rDNA amplicons collected from CKD, PUA, and TD1 showing identical sequences of Cladophora sp. use in this study. Figure S2: The water quality along the Nan River collected from February 2019 to December 2020 from locations 1-4, span the collecting time in this study in March 2020. (a) values of the water quality index, (b) dissolved oxygen, (c) biological oxygen demand, (d) ammonia nitrogen content, and (e) the locations of the water sampling stations. Table S1: Primer sequences and PCR conditions for amplification of 16S rDNA, 18S rDNA, and ITS amplicons. Table S2: Top 100 BLASTN hit of the Cladophora 18S rDNA amplicon. Table S3: Bacterial genera and their abundance found in each replicate of collecting cites CKD, PUA, and TD1. Table S4: Eukaryotic genera and their abundance found in each replicate of collecting cites CKD, PUA, and TD1. Table S5: Fungi phyla and their abundance found in TD1. Table S6: Common members of freshwater Cladophora microbiomes. Green boxes represent the presence of the corresponding taxa.

Author Contributions: Conceptualization, A.S.; methodology, A.S., K.R.-P.; validation, A.S.; formal analysis, A.S., K.R.-P.; investigation, A.S., K.R.-P.; resources, A.S.; data curation, A.S., K.R.-P.; writing—original draft preparation, A.S., K.R.-P.; writing—review and editing, A.S., K.R.-P., L.E.G.; visualization, K.R.-P.; supervision, A.S.; funding acquisition, A.S. All authors have read and agreed to the published version of the manuscript. 
Funding: This research was funded by the National Science and Technology Development Agency: A research funding project for young scientist researchers grant number FDA-CO-2561-8411-TH and Ratchadaphiseksomphot Endowment Fund, Chulalongkorn University grant number DNS 61-036-23-012-1.

Data Availability Statement: Raw amplicon metagenomic sequences were deposited in the NCBI SRA as BioProject PRJNA761577, BioSample SAMN21356006 (CKD), SAMN21356007 (PUA), and SAMN21356008 (TD1).

Acknowledgments: We thank Wikrom Chantapatchot and Adisak Lakhom for their assistance in fieldwork.

Conflicts of Interest: The authors declare no conflict of interest.

\section{References}

1. Van den Hoek, C. Revision of the European Species of Cladophora; Brill Academic Publishers: Leiden, The Netherlands, 1963.

2. Van den Hoek, C. The phytogeography of Cladophora (Chlorophyceae) in the Northern Atlantic Ocean, in comparison to that of other benthic algal species. Helgoländer Wiss. Meeresunters. 1979, 32, 374-393. [CrossRef]

3. John, D.M.; Whitton, B.A.; Brook, A.J. The Freshwater Algal Flora of the British Isles: An Identification Guide to Freshwater and Terrestrial Algae; Cambridge University Press: Cambridge, NY, USA, 2002.

4. Zulkifly, S.B.; Graham, J.M.; Young, E.B.; Mayer, R.J.; Piotrowski, M.J.; Smith, I.; Graham, L.E. The genus Cladophora Kützing (Ulvophyceae) as a globally distributed ecological engineer. J. Phycol. 2013, 49, 1-17. [CrossRef]

5. Dodds, W.; Gudder, D. The ecology of Cladophora. J. Phycol. 1992, 28, 415-427. [CrossRef]

6. Braus, M.J.; Graham, L.E.; Whitman, T.L. Spatiotemporal dynamics of the bacterial microbiota on lacustrine Cladophora glomerata (Chlorophyta). J. Phycol. 2017, 53, 1255-1262. [CrossRef]

7. Chun, C.L.; Peller, J.R.; Shively, D.; Byappanahalli, M.N.; Whitman, R.L.; Staley, C.; Zhang, Q.; Ishii, S.; Sadowsky, M.J. Virulence and biodegradation potential of dynamic microbial communities associated with decaying Cladophora in Great Lakes. Sci. Total Environ. 2017, 574, 872-880. [CrossRef]

8. Depew, D.C.; Houben, A.J.; Guildford, S.J.; Hecky, R.E. Distribution of nuisance Cladophora in the lower Great Lakes: Patterns with land use, near shore water quality and dreissenid abundance. J. Great Lakes Res. 2011, 37, 656-671. [CrossRef]

9. Graham, L.E.; Knack, J.J.; Graham, M.E.; Graham, J.M.; Zulkifly, S. A metagenome for lacustrine Cladophora (Cladophorales) reveals remarkable diversity of eukaryotic epibionts and genes relevant to materials cycling. J. Phycol. 2015, 51, 408-418. [CrossRef]

10. Zulkifly, S.; Hanshew, A.; Young, E.B.; Lee, P.; Graham, M.E.; Graham, M.E.; Piotrowski, M.; Graham, L.E. The epiphytic microbiota of the globally widespread macroalga Cladophora glomerata (Chlorophyta, Cladophorales). Am. J. Bot. 2012, 99, 1541-1552. [CrossRef]

11. Satjarak, A.; Piapukiew, J.; Chanthapatchot, W.; Ruen-Pham, K.; Vangnai, A. Herbicide atrazine alters the microbiota of the filamentous green alga cladophora sp. cultured from Thailand. Sains Malays. 2021, 50, 1255-1265. [CrossRef]

12. Dion-Phénix, H.; Charmantier, A.; de Franceschi, C.; Bourret, G.; Kembel, S.W.; Réale, D. Bacterial microbiota similarity between predators and prey in a blue tit trophic network. ISME J. 2021, 15, 1098-1107. [CrossRef]

13. Perrino, E.V.; Valerio, F.; Jallali, S.; Trani, A.; Mezzapesa, G.N. Ecological and biological properties of Satureja cuneifolia Ten. and Thymus spinulosus Ten.: Two wild officinal species of conservation concern in Apulia (Italy). a preliminary survey. Plants 2021, 10, 1952. [CrossRef]

14. Higgins, S.N.; Malkin, S.Y.; Todd Howell, E.; Guildford, S.J.; Campbell, L.; Hiriart-Baer, V.; Hecky, R.E. An ecological review of Cladophora glomerata (Chlorophyta) in the Laurentian Great Lakes. J. Phycol. 2008, 44, 839-854. [CrossRef]

15. Byappanahalli, M.N.; Sawdey, R.; Ishii, S.; Shively, D.A.; Ferguson, J.A.; Whitman, R.L.; Sadowsky, M.J. Seasonal stability of Cladophora-associated Salmonella in Lake Michigan watersheds. Water Res. 2009, 43, 806-814. [CrossRef]

16. Whitman, R.L.; Shively, D.A.; Pawlik, H.; Nevers, M.B.; Byappanahalli, M.N. Occurrence of Escherichia coli and enterococci in Cladophora (Chlorophyta) in nearshore water and beach sand of Lake Michigan. Appl. Environ. Microbiol. 2003, 69, 4714-4719. [CrossRef] [PubMed]

17. Olapade, O.A.; Depas, M.M.; Jensen, E.T.; McLellan, S.L. Microbial communities and fecal indicator bacteria associated with Cladophora mats on beach sites along Lake Michigan shores. Appl. Environ. Microbiol. 2006, 72, 1932-1938. [CrossRef]

18. Ishii, S.; Yan, T.; Shively, D.A.; Byappanahalli, M.N.; Whitman, R.L.; Sadowsky, M.J. Cladophora (Chlorophyta) spp. harbor human bacterial pathogens in nearshore water of Lake Michigan. Appl. Environ. Microbiol. 2006, 72, 4545-4553. [CrossRef]

19. Byappanahalli, M.N.; Nevers, M.B.; Przybyla-Kelly, K.; Ishii, S.; King, T.L.; Aunins, A.W. Great Lakes Cladophora harbors phylogenetically diverse nitrogen-fixing microorganisms. Environ. DNA 2019, 1, 186-195. [CrossRef]

20. Whitman, R.L.; Byappanahalli, M.; Spoljaric, A.; Przybyla-Kelly, K.; Shively, D.A.; Nevers, M. Evidence for free-living Bacteroides in Cladophora along the shores of the Great Lakes. Aquat. Microb. Ecol. 2014, 72, 117-126. [CrossRef]

21. Marsh, G.A.; Fairbridge, R.W. Lentic and lotic ecosystems. In Environmental Geology (Encyclopedia of Earth Science); Springer: Dordrecht, The Netherlands, 1999; pp. 381-388. [CrossRef] 
22. Junk, W.; Bayley, P.; Sparks, R. The flood pulse concept in river-floodplain systems. Can. Spec. Publ. Fish. Aquat. Sci. 1989, 106, 110-127.

23. Bayley, P.B. Understanding large river: Floodplain ecosystems. BioScience 1995, 45, 153-158. [CrossRef]

24. Essington, T.E.; Carpenter, S.R. Mini-review: Nutrient cycling in lakes and streams: Insights from a comparative analysis. Ecosystems 2000, 3, 131-143. [CrossRef]

25. Peerapornpisal, Y.; Amornlerdpison, D.; Rujjanawate, C.; Ruangrit, K.; Kanjanapothi, D. Two endemic species of macroalgae in Nan River, northern Thailand, as therapeutic agents. ScienceAsia 2006, 32, 71-76. [CrossRef]

26. Srimaroeng, C.; Ontawong, A.; Saowakon, N.; Vivithanaporn, P.; Pongchaidecha, A.; Amornlerdpison, D.; Soodvilai, S.; Chatsudthipong, V. Antidiabetic and renoprotective effects of Cladophora glomerata Kützing extract in experimental type 2 diabetic rats: A potential nutraceutical product for diabetic nephropathy. J. Diabetes Res. 2015, 320167. [CrossRef]

27. Laungsuwon, R.; Chulalaksananukul, W. Antioxidant and anticancer activities of freshwater green algae, Cladophora glomerata and Microspora floccosa, from Nan River in northern Thailand. Maejo Int. J. Sci. Technol. 2013, 7, 181-188. [CrossRef]

28. Laungsuwon, R.; Chulalaksananukul, W. Chemical composition and antibacterial activity of extracts from freshwater green algae, Cladophora glomerata Kützing and Microspora floccosa (Vaucher) Thuret. J. BioSci. Biotechnol. 2014, 3, 211-218.

29. Surayot, U.; Hun Lee, J.; Kanongnuch, C.; Peerapornpisal, Y.; Park, W.; You, S. Structural characterization of sulfated arabinans extracted from Cladophora glomerata Kützing and their macrophage activation. Biosci. Biotechnol. Biochem. 2016, 80, 972-982. [CrossRef] [PubMed]

30. Suanmali, W.; Moonmaun, S.; Phoomyai, P. Efficiency of antioxidant compounds from macro edible algae. J. Energy Power Eng. 2017, 11, 173-178. [CrossRef]

31. Yarnpakdee, S.; Benjakul, S.; Senphan, T. Antioxidant activity of the extracts from freshwater macroalgae (Cladophora glomerata) grown in Northern Thailand and its preventive effect against lipid oxidation of refrigerated eastern little tuna slice. Turk. J. Fish. Aquat. Sci. 2019, 19, 209-219. [CrossRef]

32. Boonprab, K.; Matsui, K.; Kataoka, N. Preliminary study on bioethanol from fresh water algae, Cladophora glomerata (Sarai Kai) by the fungus, Monascus sp. NP1. J. Appl. Phycol. 2018, 30, 137-141. [CrossRef]

33. Prescott, G.W. How to Know the Fresh-Water Algae; An Illustrated Key for Identifying the More Common Fresh-Water Algae to Genus with Hundreds of Species Named and Pictured and with Numerous Aids for Their Study; William C. Brown Company: Dubuque, IA, USA, 1964.

34. Johnson, L.P. Key to some common freshwater protozoa. Bios 1956, 27, 3-32.

35. Greeson, P.E. An Annotated Key to the Identification of Commonly Occurring and Dominant Genera of Algae Observed in the Phytoplankton of the United States; U.S. Department of the Interior: Washington, DC, USA, 1982. [CrossRef]

36. Matthews, R. Freshwater algae in Northwest Washington, Volume I. Cyanobacteria; Institute for Watershed Studies, Huxley College of the Environment, Western Washington University: Bellingham, WA, USA, 2016. [CrossRef]

37. Blanco, S. Diatom taxonomy and identification keys. In Modern Trends in Diatom Identification; Cristóbal, G., Blanco, S., Bueno, G., Eds.; Springer: Cham, Switzerland, 2020; pp. 25-38. [CrossRef]

38. Klindworth, A.; Pruesse, E.; Schweer, T.; Peplles, J.; Quast, C.; Horn, M.; Glöckner, F.O. Evaluation of general 16S ribosomal RNA gene PCR primers for classical and next-generation sequencing-based diversity studies. Nucleic Acids Res. 2013, 41, e1. [CrossRef]

39. Bradley, I.M.; Pinto, A.J.; Guest, J.S. Design and evaluation of Illumina MiSeq-compatible, $18 \mathrm{~S}$ rRNA gene-specific primers for improved characterization of mixed phototrophic communities. Appl. Environ. Microbiol. 2016, 82, 5878-5891. [CrossRef]

40. Gardes, M.; Bruns, T.D. ITS primers with enhanced specificity for basidiomycetes-application to the identification of mycorrhizae and rusts. Mol. Ecol. 1993, 2, 113-118. [CrossRef]

41. White, T.J.; Bruns, T.; Lee, S.; Taylor, J. Amplification and direct sequencing of fungal ribosomal RNA genes for phylogenetics. In PCR Protocols: A Guide to Methods and Applications; Innis, M.A., Gelfand, D.H., Eds.; Academic Press, Inc.: London, UK, 1990; pp. 315-322.

42. Andrews, S. FastQC: A Quality Control Tool for High Throughput Sequence Data 2010. Available online: http://www. bioinformatics.babraham.ac.uk/projects / fastqc (accessed on 10 September 2020).

43. Bolger, A.M.; Lohse, M.; Usadel, B. Trimmomatic: A flexible trimmer for Illumina sequence data. Bioinformatics 2014, 30, 2114-2120. [CrossRef]

44. Quast, C.; Pruesse, E.; Yilmaz, P.; Gerken, J.; Schweer, T.; Yarza, P.; Peplies, J.; Glöckner, F.O. The SILVA ribosomal RNA gene database project: Improved data processing and web-based tools. Nucleic Acids Res. 2013, 41, D590-D596. [CrossRef]

45. Li, W.; Godzik, A. Cd-hit: A fast program for clustering and comparing large sets of protein or nucleotide sequences. Bioinformatics 2006, 22, 1658-1659. [CrossRef]

46. Rognes, T.; Flouri, T.; Nichols, B.; Quince, C.; Mahe, F. VSEARCH: A versatile open source tool for metagenomics. PeerJ 2016, 4, e2584. [CrossRef]

47. Afgan, E.; Baker, D.; Batut, B.; van den Beek, M.; Bouvier, D.; Čech, M.; Chilton, J.; Clements, D.; Coraor, N.; Grüning, B.A.; et al. The Galaxy platform for accessible, reproducible and collaborative biomedical analyses: 2018 update. Nucleic Acids Res. 2018, 46, W537-W544. [CrossRef]

48. Nilsson, R.H.; Larsson, K.H.; Taylor, A.F.S.; Bengtsson-Palme, J.; Jeppesen, T.S.; Schigel, D.; Kennedy, P.; Picard, K.; Glöckner, F.O.; Tedersoo, L.; et al. The UNITE database for molecular identification of fungi: Handling dark taxa and parallel taxonomic classifications. Nucleic Acids Res. 2019, 47, D259-D264. [CrossRef] 
49. Nilsson, R.H.; Tedersoo, L.; Ryberg, M.; Kristiansson, E.; Hartmann, M.; Unterseher, M.; Porter, T.M.; Bengtsson-Palme, J.; Walker, D.M.; De Sousa, F.; et al. A comprehensive, automatically updated fungal ITS sequence dataset for reference-based chimera control in environmental sequencing efforts. Microbes Environ. 2015, 30, 145-150. [CrossRef]

50. Oksanen, J.; Blanchet, F.G.; Friendly, M.; Kindt, R.; Legendre, P.; McGlinn, D.; Minchin, P.R.; O’Hara, R.B.; Simpson, G.L.; Solymos, P.; et al. Vegan: Community Ecology Package, R Package Version 2.5-7. 2020. Available online: http:/ /CRAN.R-project. org / package=vegan (accessed on 15 March 2020).

51. RStudio Team. RStudio: Integrated Development Environment for R; RStudio, Inc.: Boston, MA, USA, 2021; Available online: http:/ / www.rstudio.com/ (accessed on 15 March 2021).

52. De Mendiburu, F. Agricolae: Statistical Procedures for Agricultural Research. Available online: https://CRAN.R-project.org/ package=agricolae (accessed on 15 March 2020).

53. Wickham, H. ggplot2: Elegant Graphics for Data Analysis; Springer: New York, NY, USA, 2018. [CrossRef]

54. Boedeker, C.; Leliaert, F.; Zuccarello, G.C. Molecular phylogeny of the Cladophoraceae (Cladophorales, Ulvophyceae), with the resurrection of Acrocladus Nägeli and Willeella Børgesen, and the description of Lurbica gen. nov. and Pseudorhizoclonium gen. nov. J. Phycol. 2016, 52, 905-928. [CrossRef] [PubMed]

55. Thiamdao, S.; Boo, G.H.; Boo, S.M.; Peerapornpisal, Y. Diversity of edible Cladophora (Cladophorales, Chlorophyta) in Northern and Northeastern Thailand, based on morphology and nuclear ribosomal DNA sequences. Chiang Mai J. Sci. 2012, 39, 300-310.

56. Bengtsson, M.M.; Wagner, K.; Schwab, C.; Urich, T.; Battin, T.J. Light availability impacts structure and function of phototrophic stream biofilms across domains and trophic levels. Mol Ecol. 2018, 27, 2913-2925. [CrossRef]

57. Bahulikar, R.A.; Kroth, P.G. Localization of EPS components secreted by freshwater diatoms using differential staining with fluorophore-conjugated lectins and other fluorochromes. Eur. J. Phycol. 2007, 42, 199-208. [CrossRef]

58. Huntsman, S.A.; Sloneker, J.H. An exocellular polysaccharide from the diatom Gomphonema olivaceum. J. Phycol. 1971, 7, 261-264. [CrossRef]

59. Danilov, R.; Ekelund, N.G.A. The efficiency of seven diversity and one similarity indices based on phytoplankton data for assessing the level of eutrophication in lakes in central Sweden. Sci. Total Environ. 1999, 234, 15-23. [CrossRef]

60. Spatharis, S.; Roelke, D.L.; Dimitrakopoulos, P.G.; Kokkoris, G.D. Analyzing the (mis)behavior of Shannon index in eutrophication studies using field and simulated phytoplankton assemblages. Ecol. Indic. 2011, 11, 697-703. [CrossRef]

61. Lee, T.C.; Liu, C.C.K. Assessing eutrophication potential of a freshwater lake by relating its bioproductivity and biodiversity: A case study of Lake Wilson on Central Oahu, Hawaii. Water 2018, 10, 296. [CrossRef]

62. Heylen, K.; Lebbe, L.; De Vos, P. Acidovorax caeni sp. nov., a denitrifying species with genetically diverse isolates from activated sludge. Int. J. Syst. Evol. Microbiol. 2008, 58, 73-77. [CrossRef] [PubMed]

63. Feng, L.; Yang, J.; Yu, H.; Lan, Z.; Ye, X.; Yang, G.; Yang, Q.; Zhou, J. Response of denitrifying community, denitrification genes and antibiotic resistance genes to oxytetracycline stress in polycaprolactone supported solid-phase denitrification reactor. Bioresour. Technol. 2020, 308, 123274. [CrossRef]

64. Bazylinski, D.A.; Palome, E.; Blakemore, N.A.; Blakemore, R.P. Denitrification by Chromobacterium violaceum. Appl. Environ. Microbiol. 1986, 52, 696-699. [CrossRef] [PubMed]

65. Chen, Y.; Shao, Z.; Kong, Z.; Gu, L.; Fang, J.; Chai, H. Study of pyrite based autotrophic denitrification system for low-carbon source stormwater treatment. J. Water Process. Eng. 2020, 37, 101414. [CrossRef]

66. Zhang, Q.; Ji, F.; Xu, X. Effects of physicochemical properties of poly-epsilon-caprolactone on nitrate removal efficiency during solid-phase denitrification. Chem. Eng. J. 2016, 283, 604-613. [CrossRef]

67. Tanikawa, D.; Nakamura, Y.; Tokuzawa, H.; Hirakata, Y.; Hatamoto, M.; Yamaguchi, T. Effluent treatment in an aquaponicsbased closed aquaculture system with single-stage nitrification-denitrification using a down-flow hanging sponge reactor. Int. Biodeterior. Biodegrad. 2018, 132, 268-273. [CrossRef]

68. Martineau, C.; Mauffrey, F.; Villemur, R. Comparative analysis of denitrifying activities of Hyphomicrobium nitrativorans, Hyphomicrobium denitrificans, and Hyphomicrobium zavarzinii. Appl. Environ. Microbiol. 2015, 81, 5003-5014. [CrossRef]

69. Kalyuhznaya, M.G.; Martens-Habbena, W.; Wang, T.; Hackett, M.; Stolyar, S.M.; Stahl, D.A.; Lidstrom, M.E.; Chistoserdova, L. Methylophilaceae link methanol oxidation to denitrification in freshwater lake sediment as suggested by stable isotope probing and pure culture analysis. Environ. Microbiol. Rep. 2009, 1, 385-392. [CrossRef]

70. Zhang, L.; Hao, S.; Wang, Y.; Lan, S.; Dou, Q.; Peng, Y. Rapid start-up strategy of partial denitrification and microbially driven mechanism of nitrite accumulation mediated by dissolved organic matter. Bioresour. Technol. 2021, 340, 125663. [CrossRef]

71. Qi, W.; Taherzadeh, M.J.; Ruan, Y.; Deng, Y.; Chen, J.S.; Lu, H.F.; Xu, X.Y. Denitrification performance and microbial communities of solid-phase denitrifying reactors using poly (butylene succinate)/bamboo powder composite. Bioresour. Technol. 2020, 305, 123033. [CrossRef]

72. Liu, B.; Mao, Y.; Bergaust, L.; Bakken, L.R.; Frostegard, A. Strains in the genus Thauera exhibit remarkably different denitrification regulatory phenotypes. Environ. Microbiol. 2013, 15, 2816-2828. [CrossRef]

73. Huang, W.; Gong, B.; He, L.; Wang, Y.; Zhou, J. Intensified nutrients removal in a modified sequencing batch reactor at low temperature: Metagenomic approach reveals the microbial community structure and mechanisms. Chemosphere 2020, $244,125513$. [CrossRef]

74. Zhao, Y.; Bu, C.; Yang, H.; Qiao, Z.; Ding, S.; Ni, S.-Q. Survey of dissimilatory nitrate reduction to ammonium microbial community at national wetland of Shanghai, China. Chemosphere 2020, 250, 126195. [CrossRef] 
75. Beller, H.R.; Han, R.; Karaoz, U.; Lim, H.; Brodie, E.L. Genomic and physiological characterization of the chromate-reducing, aquifer-derived Firmicute Pelosinus sp. strain HCF1. Appl. Environ. Microbiol. 2013, 79, 63-73. [CrossRef]

76. Khramenkov, S.V.; Kozlov, M.N.; Kevbrina, M.V.; Dorofeev, A.G.; Kazakova, E.A.; Grachev, V.A.; Kuznetsov, B.B.; Polyakov, D.Y.; Nikolaev, Y.A. A novel bacterium carrying out anaerobic ammonium oxidation in a reactor for biological treatment of the filtrate of wastewater fermented sludge. Microbiology 2013, 82, 628-636. [CrossRef]

77. Muwawa, E.M.; Obieze, C.C.; Makonde, H.M.; Jefwa, J.M.; Kahindi, J.H.P.; Khasa, D.P. 16S rRNA gene amplicon-based metagenomic analysis of bacterial communities in the rhizospheres of selected mangrove species from Mida Creek and Gazi Bay, Kenya. PLoS ONE 2021, 16, e0248485. [CrossRef]

78. Podlesnaya, G.V.; Krasnopeev, A.Y.; Potapov, S.A.; Tikhonova, I.V.; Shtykova, Y.R.; Suslova, M.Y.; Timoshkin, O.A.; Belykh, O.I. Diversity of nitrifying bacteria in microbial communities from water and epilithic biofilms of the Lake Baikal littoral zone. Limnol. Freshw. Biol. 2020, 4, 1008-1010. [CrossRef]

79. Tian, M.; Zhao, F.; Shen, X.; Chu, K.; Wang, J.; Chen, S.; Guo, Y.; Liu, H. The first metagenome of activated sludge from full-scale anaerobic/anoxic/oxic (A2O) nitrogen and phosphorus removal reactor using Illumina sequencing. J. Environ. Sci. 2015, 35, 181-190. [CrossRef] [PubMed]

80. Wu, Y.F.; Chai, C.W.; Li, Y.N.; Chen, J.; Yuan, Y.; Hu, G.; Rosen, B.P.; Zhang, J. Anaerobic As (III) oxidation coupled with nitrate reduction and attenuation of dissolved Arsenic by Noviherbaspirillum Species. ACS Earth Space Chem. 2021, 5, 2115-2123. [CrossRef]

81. Goto, M.; Kuwata, H. Rhizobacter daucus gen. nov., sp. nov., the causal agent of carrot bacterial gall. Int. J. Syst. Evol. Microbiol. 1988, 38, 233-239. [CrossRef]

82. Hubert, C.; Voordouw, G. Oil field souring control by nitrate-reducing Sulfurospirillum spp. that outcompete sulfate-reducing bacteria for organic electron donors. Appl. Environ. Microbiol. 2007, 73, 2644-2652. [CrossRef]

83. Rameshkumar, N.; Lang, E.; Tanaka, N. Description of Vogesella oryzae sp. nov., isolated from the rhizosphere of saline tolerant pokkali rice. Syst. Appl. Microbiol. 2016, 39, 20-24. [CrossRef]

84. Ishii, K.; Fujitani, H.; Sekiguchi, Y.; Tsuneda, S. Physiological and genomic characterization of a new 'Candidatus Nitrotoga' isolate. Environ. Microbiol. 2020, 22, 2365-2382. [CrossRef] [PubMed]

85. McIlroy, S.J.; Starnawska, A.; Starnawski, P.; Saunders, A.M.; Nierychlo, M.; Nielsen, P.H.; Nielsen, J.L. Identification of active denitrifiers in full-scale nutrient removal wastewater treatment systems. Environ. Microbiol. 2016, 18, 50-64. [CrossRef]

86. Hougardy, A.; Klemme, J.-H. Nitrate reduction in a new strain of Rhodoferax fermentans. Arch. Microbiol. 1995, 164, 358-362. [CrossRef]

87. Masuda, Y.; Yamanaka, H.; Xu, Z.X.; Shiratori, Y.; Aono, T.; Amachi, S.; Senoo, K.; Itoh, H. Diazotrophic anaeromyxobacter isolates from soils. Appl. Environ. Microbiol. 2020, 86, e00956-20. [CrossRef]

88. Bae, H.S.; Rash, B.A.; Rainey, F.A.; Nobre, M.F.; Tiago, I.; da Costa, M.S.; Moe, W.M. Description of Azospira restricta sp. nov., a nitrogen-fixing bacterium isolated from groundwater. Int. J. Syst. Evol. Microbiol. 2007, 57, 1521-1526. [CrossRef] [PubMed]

89. Salinero, K.K.; Keller, K.; Feil, W.S.; Feil, H.; Trong, S.; Di Bartolo, G.; Lapidus, A. Metabolic analysis of the soil microbe Dechloromonas aromatica str. RCB: Indications of a surprisingly complex life-style and cryptic anaerobic pathways for aromatic degradation. BMC Genom. 2009, 10, 351. [CrossRef]

90. Rivas, R.; Velázquez, E.; Willems, A.; Vizcaíno, N.; Subba-Rao, N.S.; Mateos, P.F.; Gillis, M.; Dazzo, F.B.; Martínez-Molina, E. A new species of Devosia that forms a unique nitrogen-fixing root-nodule symbiosis with the aquatic legume Neptunia natans (Lf) Druce. Appl. Environ. Microbiol. 2002, 68, 5217-5222. [CrossRef]

91. Laranjo, M.; Alexandre, A.; Oliveira, S. Legume growth-promoting rhizobia: An overview on the Mesorhizobium genus. Microbiol. Res. 2014, 169, 2-17. [CrossRef] [PubMed]

92. Takeda, K. Characteristics of a nitrogen-fixing methanotroph, Methylocystis T-1. Antonie Van Leeuwenhoek 1988, 54, 521-534. [CrossRef] [PubMed]

93. Yu, X.; Kang, X.; Li, Y.; Cui, Y.; Tu, W.; Shen, T.; Yan, M.; Gu, Y.; Zou, L.; Ma, M.; et al. Rhizobia population was favoured during in situ phytoremediation of vanadium-titanium magnetite mine tailings dam using Pongamia pinnata. Environ. Pollut. 2019, 255, 113167. [CrossRef]

94. Xie, C.H.; Yokota, A. Reclassification of Alcaligenes latus strains IAM 12599T and IAM 12664 and Pseudomonas saccharophila as Azohydromonas lata gen. nov., comb. nov., Azohydromonas australica sp. nov. and Pelomonas saccharophila gen. nov., comb. nov., respectively. Int. J. Syst. Evol. Microbiol. 2005, 55, 2419-2425. [CrossRef]

95. Sheu, S.Y.; Huang, H.W.; Young, C.C.; Chen, W.M. Rhizobium alvei sp. nov., isolated from a freshwater river. Int. J. Syst. Evol. Microbiol. 2015, 65, 472-478. [CrossRef] [PubMed]

96. Taulé, C.; Castillo, A.; Villar, S.; Olivares, F.; Battistoni, F. Endophytic colonization of sugarcane (Saccharum officinarum) by the novel diazotrophs Shinella sp. UYSO24 and Enterobacter sp. UYSO10. Plant Soil 2016, 403, 403-418. [CrossRef]

97. Park, D.; Kim, H.; Yoon, S. Nitrous oxide reduction by an obligate aerobic bacterium, Gemmatimonas aurantiaca strain T-27. Appl. Environ. Microbiol. 2017, 83, e00502-17. [CrossRef]

98. Gülay, A.; Cekic, Y.; Musovic, S.; Albrechtsen, H.J.; Smets, B.F. Diversity of iron oxidizers in groundwater-fed rapid sand filters: Evidence of Fe(II)-dependent growth by Curvibacter and Undibacterium spp. Front. Microbiol. 2018, 9, 2808. [CrossRef]

99. Peng, H.; Zhang, Q.; Tan, B.; Li, M.; Zhang, W.; Feng, J. A metagenomic view of how different carbon sources enhance the aniline and simultaneous nitrogen removal capacities in the aniline degradation system. Bioresour. Technol. 2021, 335, 125277. [CrossRef] 
100. Liu, J.; Wang, Z.; Belchik, S.M.; Edwards, M.J.; Liu, C.; Kennedy, D.W.; Merkley, E.D.; Lipton, M.S.; Butt, J.N.; Richardson, D.J.; et al. Identification and characterization of MtoA: A decaheme c-type cytochrome of the neutrophilic Fe (II)-oxidizing bacterium Sideroxydans lithotrophicus ES-1. Front. Microbiol. 2012, 3, 37. [CrossRef]

101. Falagan, C.; Johnson, D.B. Acidibacter ferrireducens gen. nov., sp. nov.: An acidophilic ferric iron-reducing gammaproteobacterium. Extremophiles 2014, 18, 1067-1073. [CrossRef] [PubMed]

102. Ridge, J.P.; Lin, M.; Larsen, E.I.; Fegan, M.; McEwan, A.G.; Sly, L.I. A multicopper oxidase is essential for manganese oxidation and laccase-like activity in Pedomicrobium sp. ACM 3067. Environ. Microbiol. 2007, 9, 944-953. [CrossRef]

103. Seviour, R.J.; Mino, T.; Onuki, M. The microbiology of biological phosphorus removal in activated sludge systems. FEMS Microbiol. Rev. 2003, 27, 99-127. [CrossRef]

104. Chai, X.; Wu, B.; Xu, Z.; Yang, N.; Song, L.; Mai, J.; Chen, Y.; Dai, X. Ecosystem activation system (EAS) technology for remediation of eutrophic freshwater. Sci. Rep. 2017, 7, 4818. [CrossRef] [PubMed]

105. Li, C.; Liu, S.; Ma, T.; Zheng, M.; Ni, J. Simultaneous nitrification, denitrification and phosphorus removal in a sequencing batch reactor (SBR) under low temperature. Chemosphere 2019, 229, 132-141. [CrossRef]

106. Taylor, J.; Parkes, R.J. The cellular fatty acids of the sulphate-reducing bacteria, Desulfobacter sp., Desulfobulbus sp. and Desulfovibrio desulfuricans. Microbiology 1983, 129, 3303-3309. [CrossRef]

107. Copeland, A.; Spring, S.; Göker, M.; Schneider, S.; Lapidus, A.; Del Rio, T.G.; Tice, H.; Cheng, J.-F.; Chen, F.; Nolan, M.; et al. Complete genome sequence of Desulfomicrobium baculatum type strain ( $\left.\mathrm{X}^{\mathrm{T}}\right)$. Stand. Genomic Sci. 2009, 1, 29-37. [CrossRef] [PubMed]

108. Karnachuk, O.V.; Rusanov, I.I.; Panova, I.A.; Grigoriev, M.A.; Zyusman, V.S.; Latygolets, E.A.; Kadyrbaev, M.K.; Gruzdev, E.V.; Beletsky, A.V.; Mardanov, A.V.; et al. Microbial sulfate reduction by Desulfovibrio is an important source of hydrogen sulfide from a large swine finishing facility. Sci. Rep. 2021, 11, 10720. [CrossRef]

109. Chen, Y.; Feng, X.; He, Y.; Wang, F. Genome analysis of a Limnobacter sp. identified in an anaerobic methane-consuming cell consortium. Front. Mar. Sci. 2016, 3, 257. [CrossRef]

110. Sun, W.; Xiao, E.; Häggblom, M.; Krumins, V.; Dong, Y.; Sun, X.; Li, F.; Wang, Q.; Li, B.; Yan, B. Bacterial survival strategies in an alkaline tailing site and the physiological mechanisms of dominant phylotypes as revealed by metagenomic analyses. Environ. Sci. Technol. 2018, 52, 13370-13380. [CrossRef] [PubMed]

111. Fadhlaoui, K.; Ben Hania, W.; Postec, A.; Fauque, G.; Hamdi, M.; Ollivier, B.; Fardeau, M.-L. Fusibacter fontis sp. nov., a sulfurreducing, anaerobic bacterium isolated from a mesothermic Tunisian spring. Int. J. Syst. Evol. Microbiol. 2015, 65, 3501-3506. [CrossRef]

112. North, N.N.; Dollhopf, S.L.; Petrie, L.; Istok, J.D.; Balkwill, D.L.; Kostka, J.E. Change in bacterial community structure during in situ biostimulation of subsurface sediment cocontaminated with uranium and nitrate. Appl. Environ. Microbiol. 2004, 70, 4911-4920. [CrossRef]

113. Masuda, H.; Shiwa, Y.; Yoshikawa, H.; Zylstra, G.J. Draft genome sequence of the versatile alkane-degrading bacterium Aquabacterium sp. strain NJ1. Genome Announc. 2014, 2, e01271-14. [CrossRef]

114. Harwati, T.U.; Kasai, Y.; Kodama, Y.; Susilaningsih, D.; Watanabe, K. Tropicimonas isoalkanivorans gen. nov., sp. nov., a branchedalkane-degrading bacterium isolated from Semarang Port in Indonesia. Int. J. Syst. Evol. Microbiol. 2009, 59, 388-391. [CrossRef] [PubMed]

115. Woo, H.L.; Hazen, T.C.; Simmons, B.A.; DeAngelis, K.M. Enzyme activities of aerobic lignocellulolytic bacteria isolated from wet tropical forest soils. Syst. Appl. Microbiol. 2014, 37, 60-67. [CrossRef]

116. Hatamoto, M.; Kaneshige, M.; Nakamura, A.; Yamaguchi, T. Bacteroides luti sp. nov., an anaerobic, cellulolytic and xylanolytic bacterium isolated from methanogenic sludge. Int. J. Syst. Evol. Microbiol. 2014, 64, 1770-1774. [CrossRef] [PubMed]

117. Song, N.; Cai, H.-Y.; Yan, Z.-S.; Jiang, H.-L. Cellulose degradation by one mesophilic strain Caulobacter sp. FMC1 under both aerobic and anaerobic conditions. Bioresour. Technol. 2013, 131, 281-287. [CrossRef] [PubMed]

118. DeBoy, R.T.; Mongodin, E.F.; Fouts, D.E.; Tailford, L.E.; Khouri, H.; Emerson, J.B.; Mohamoud, Y.; Watkins, K.; Henrissat, B.; Gilbert, H.J.; et al. Insights into plant cell wall degradation from the genome sequence of the soil bacterium Cellvibrio japonicus. J. Bacteriol. 2008, 190, 5455-5463. [CrossRef] [PubMed]

119. Cui, J.; Mai, G.; Wang, Z.; Liu, Q.; Zhou, Y.; Ma, Y.; Liu, C. Metagenomic insights into a cellulose-rich niche reveal microbial cooperation in cellulose degradation. Front. Microbiol. 2019, 10, 618. [CrossRef]

120. Xie, G.; Bruce, D.C.; Challacombe, J.F.; Chertkov, O.; Detter, J.C.; Gilna, P.; Han, C.S.; Lucas, S.; Misra, M.; Myers, G.L.; et al. Genome sequence of the cellulolytic gliding bacterium Cytophaga hutchinsonii. Appl. Environ. Microbiol. 2007, 73, 3536-3546. [CrossRef]

121. Cai, L.; Chen, T.-B.; Zheng, S.-W.; Liu, H.-T.; Zheng, G.-D. Decomposition of lignocellulose and readily degradable carbohydrates during sewage sludge biodrying, insights of the potential role of microorganisms from a metagenomic analysis. Chemosphere 2018, 201, 127-136. [CrossRef]

122. Co, R.; Hug, L.A. Prediction, enrichment and isolation identify a responsive, competitive community of cellulolytic microorganisms from a municipal landfill. FEMS Microbiol. Ecol. 2021, 97, fiab065. [CrossRef]

123. Ravachol, J.; de Philip, P.; Borne, R.; Mansuelle, P.; Maté, M.J.; Perret, S.; Fierobe, H.-P. Mechanisms involved in xyloglucan catabolism by the cellulosome-producing bacterium Ruminiclostridium cellulolyticum. Sci. Rep. 2016, 6, 22770. [CrossRef] 
124. Gao, C.; Zhang, A.; Chen, K.; Hao, Z.; Tong, J.; Ouyang, P. Characterization of extracellular chitinase from Chitinibacter sp. GC72 and its application in GlcNAc production from crayfish shell enzymatic degradation. Biochem. Eng. J. 2015, 97, 59-64. [CrossRef]

125. Joung, Y.; Lee, B.-I.; Kang, H.; Kim, H.; Joh, K. Chitinimonas viridis sp. nov., isolated from a mesotrophic artificial lake. Int. J. Syst. Evol. Microbiol. 2014, 64, 1123-1126. [CrossRef]

126. Chen, Q.; Meyer, W.A.; Zhang, Q.; White, J.F. 16S rRNA metagenomic analysis of the bacterial community associated with turf grass seeds from low moisture and high moisture climates. Peerj 2020, 8, e8417. [CrossRef]

127. Kulichevskaya, I.S.; Naumoff, D.G.; Ivanova, A.A.; Rakitin, A.L.; Dedysh, S.N. Detection of chitinolytic capabilities in the freshwater Planctomycete Planctomicrobium piriforme. Microbiology 2019, 88, 423-432. [CrossRef]

128. Vedler, E.; Heinaru, E.; Jutkina, J.; Viggor, S.; Koressaar, T.; Remm, M.; Heinaru, A. Limnobacter spp. as newly detected phenoldegraders among Baltic Sea surface water bacteria characterised by comparative analysis of catabolic genes. Syst. Appl. Microbiol. 2013, 36, 525-532. [CrossRef] [PubMed]

129. Fan, X.; Nie, L.; Shi, K.; Wang, Q.; Xia, X.; Wang, G. Simultaneous 3-/4-hydroxybenzoates biodegradation and arsenite oxidation by Hydrogenophaga sp. H7. Front. Microbiol. 2019, 10, 1346. [CrossRef] [PubMed]

130. Kim, E.; Yulisa, A.; Kim, S.; Hwang, S. Monitoring microbial community structure and variations in a full-scale petroleum refinery wastewater treatment plant. Bioresour. Technol. 2020, 306, 123178. [CrossRef] [PubMed]

131. Kane, S.R.; Chakicherla, A.Y.; Chain, P.S.G.; Schmidt, R.; Shin, M.W.; Legler, T.C.; Scow, K.M.; Larimer, F.W.; Lucas, S.M.; Richardson, P.M.; et al. Whole-genome analysis of the methyl tert-butyl ether-degrading beta-proteobacterium Methylibium petroleiphilum PM1. J. Bacteriol. 2007, 189, 1931-1945. [CrossRef]

132. Mechichi, T.; Stackebrandt, E.; Gad'on, N.; Fuchs, G. Phylogenetic and metabolic diversity of bacteria degrading aromatic compounds under denitrifying conditions, and description of Thauera phenylacetica sp. nov., Thauera aminoaromatica sp. nov., and Azoarcus buckelii sp. nov. Arch. Microbiol. 2002, 178, 26-35. [CrossRef]

133. Verma, H.; Dhingra, G.G.; Sharma, M.; Gupta, V.; Negi, R.K.; Singh, Y.; Lal, R. Comparative genomics of Sphingopyxis spp. unravelled functional attributes. Genomics 2020, 112, 1956-1969. [CrossRef]

134. Shu, D.; He, Y.; Yue, H.; Zhu, L.; Wang, Q. Metagenomic insights into the effects of volatile fatty acids on microbial community structures and functional genes in organotrophic anammox process. Bioresour. Technol. 2015, 196, 621-633. [CrossRef]

135. Kumar, V.; Chandra, R. Metagenomics analysis of rhizospheric bacterial communities of Saccharum arundinaceum growing on organometallic sludge of sugarcane molasses-based distillery. 3 Biotech 2020, 10, 316. [CrossRef]

136. Raux, E.; Lanois, A.; Warren, M.J.; Rambach, A.; Thermes, C. Cobalamin (vitamin $\mathrm{B}_{12}$ ) biosynthesis: Identification and characterization of a Bacillus megaterium cobI operon. Biochem. J. 1998, 335, 159-166. [CrossRef] [PubMed]

137. Brewer, T.E.; Handley, K.M.; Carini, P.; Gilbert, J.A.; Fierer, N. Genome reduction in an abundant and ubiquitous soil bacterium 'Candidatus Udaeobacter copiosus'. Nat. Microbiol. 2016, 2, 16198. [CrossRef]

138. Tekedar, H.C.; Karsi, A.; Reddy, J.S.; Nho, S.W.; Kalindamar, S.; Lawrence, M.L. Comparative genomics and transcriptional analysis of Flavobacterium columnare strain ATCC 49512. Front. Microbiol. 2017, 8, 588. [CrossRef] [PubMed]

139. Krohn-Molt, I.; Alawi, M.; Förstner, K.U.; Wiegandt, A.; Burkhardt, L.; Indenbirken, D.; Thieß, M.; Grundhoff, A.; Kehr, J.; Tholey, A.; et al. Insights into microalga and bacteria interactions of selected phycosphere biofilms using metagenomic, transcriptomic, and proteomic approaches. Front. Microbiol. 2017, 8, 1941. [CrossRef] [PubMed]

140. Roper, J.M.; Raux, E.; Brindley, A.A.; Schubert, H.L.; Gharbia, S.E.; Shah, H.N.; Warren, M.J. The enigma of cobalamin (vitamin $\mathrm{B}_{12}$ ) biosynthesis in Porphyromonas gingivalis: Identification and characterization of a functional corrin pathway. J. Biol. Chem. 2000, 275, 40316-40323. [CrossRef]

141. Cameron, B.; Briggs, K.; Pridmore, S.; Brefort, G.; Crouzet, J. Cloning and analysis of genes involved in coenzyme $B_{12}$ biosynthesis in Pseudomonas denitrificans. J. Bacteriol. 1989, 171, 547-557. [CrossRef]

142. Kurmayer, R.; Christiansen, G.; Holzinger, A.; Rott, E. Single colony genetic analysis of epilithic stream algae of the genus Chamaesiphon spp. Hydrobiologia 2018, 811, 61-75. [CrossRef]

143. Komárek, J.; Kopecký, J.; Cepák, V. Generic characters of the simplest cyanoprokaryotes Cyanobium, Cyanobacterium and Synechococcus. Cryptogam. Algol. 1999, 20, 209-222. [CrossRef]

144. Herter, S.; Fuchs, G.; Bacher, A.; Eisenreich, W. A bicyclic autotrophic $\mathrm{CO}_{2}$ fixation pathway in Chloroflexus aurantiacus. J. Biol. Chem. 2002, 277, 20277-20283. [CrossRef] [PubMed]

145. Yan, S.; Fuchs, B.M.; Lenk, S.; Harder, J.; Wulf, J.; Jiao, N.-Z.; Amann, R. Biogeography and phylogeny of the NOR5/OM60 clade of Gammaproteobacteria. Syst. Appl. Microbiol. 2009, 32, 124-139. [CrossRef]

146. Yutin, N.; Béjà, O. Putative novel photosynthetic reaction centre organizations in marine aerobic anoxygenic photosynthetic bacteria: Insights from metagenomics and environmental genomics. Environ. Microbiol. 2005, 7, 2027-2033. [CrossRef]

147. Jung, D.O.; Achenbach, L.A.; Karr, E.A.; Takaichi, S.; Madigan, M.T. A gas vesiculate planktonic strain of the purple non-sulfur bacterium Rhodoferax antarcticus isolated from Lake Fryxell, Dry Valleys, Antarctica. Arch. Microbiol. 2004, 182, 236-243. [CrossRef] [PubMed]

148. Tarhriz, V.; Hirose, S.; Fukushima, S.-I.; Hejazi, M.A.; Imhoff, J.F.; Thiel, V.; Hejazi, M.S. Emended description of the genus Tabrizicola and the species Tabrizicola aquatica as aerobic anoxygenic phototrophic bacteria. Antonie Van Leeuwenhoek 2019, 112, 1169-1175. [CrossRef]

149. Li, R.Y.; Fang, H.H.P. Hydrogen production characteristics of photoheterotrophic Rubrivivax gelatinosus L31. Int. J. Hydrog. Energy 2008, 33, 974-980. [CrossRef] 
150. Tamaki, H.; Tanaka, Y.; Matsuzawa, H.; Muramatsu, M.; Meng, X.-Y.; Hanada, S.; Mori, K.; Kamagata, Y. Armatimonas rosea gen. nov., sp. nov., of a novel bacterial phylum, Armatimonadetes phyl. nov., formally called the candidate phylum OP10. Int. J. Syst. Evol. Microbiol. 2011, 61, 1442-1447. [CrossRef] [PubMed]

151. Kulichevskaya, I.S.; Ivanova, A.A.; Baulina, O.I.; Rijpstra, W.I.C.; Sinninghe Damsté, J.S.; Dedysh, S.N. Fimbriiglobus ruber gen. nov., sp. nov., a Gemmata-like planctomycete from Sphagnum peat bog and the proposal of Gemmataceae fam. nov. Int. J. Syst. Evol. Microbiol. 2017, 67, 218-224. [CrossRef]

152. Yoon, M.-H.; Im, W.-T. Flavisolibacter ginsengiterrae gen. nov., sp. nov. and Flavisolibacter ginsengisoli sp. nov., isolated from ginseng cultivating soil. Int. J. Syst. Evol. Microbiol. 2007, 57, 1834-1839. [CrossRef]

153. Schlesner, H.; Bartels, C.; Sittig, M.; Dorsch, M.; Stackebrandt, E. Taxonomic and phylogenetic studies on a new taxon of budding, hyphal Proteobacteria, Hirschia baltica gen. nov., sp. nov. Int. J. Syst. Evol. Microbiol. 1990, 40, 443-451. [CrossRef]

154. Khan, S.T.; Fukunaga, Y.; Nakagawa, Y.; Harayama, S. Emended descriptions of the genus Lewinella and of Lewinella cohaerens, Lewinella nigricans and Lewinella persica, and description of Lewinella lutea sp. nov. and Lewinella marina sp. nov. Int. J. Syst. Evol. Microbiol. 2007, 57, 2946-2951. [CrossRef] [PubMed]

155. Chen, Z.; Lei, X.; Lai, Q.; Li, Y.; Zhang, B.; Zhang, J.; Zhang, H.; Yang, L.; Zheng, W.; Tian, Y.; et al. Phaeodactylibacter xiamenensis gen. nov., sp. nov., a member of the family Saprospiraceae isolated from the marine alga Phaeodactylum tricornutum. Int. J. Syst. Evol. Microbiol. 2014, 64, 3496-3502. [CrossRef]

156. Watanabe, M.; Kojima, H.; Fukui, M. Aerosticca soli gen. nov., sp. nov., an aerobic gammaproteobacterium isolated from crude oil-contaminated soil. Arch. Microbiol. 2020, 202, 1069-41076. [CrossRef] [PubMed]

157. Albuquerque, L.; Santos, J.; Travassos, P.; Nobre, M.F.; Rainey, F.A.; Wait, R.; Empadinhas, N.; Silva, M.T.; da Costa, M.S. Albidovulum inexpectatum gen. nov., sp. nov., a nonphotosynthetic and slightly thermophilic bacterium from a marine hot spring that is very closely related to members of the photosynthetic genus Rhodovulum. Appl. Environ. Microbiol. 2002, 68, 4266-4273. [CrossRef]

158. Kulichevskaya, I.S.; Suzina, N.E.; Liesack, W.; Dedysh, S.N. Bryobacter aggregatus gen. nov., sp. nov., a peat-inhabiting, aerobic chemo-organotroph from subdivision 3 of the Acidobacteria. Int. J. Syst. Evol. Microbiol. 2010, 60, 301-306. [CrossRef]

159. Vandamme, P.; Bernardet, J.-F.; Segers, P.; Kersters, K.; Holmes, B. New perspectives in the classification of the flavobacteria: Description of Chryseobacterium gen. nov., Bergeyella gen-nov, and Empedobacter nom-rev. Int. J. Syst. Evol. Microbiol. 1994, 44, 827-831. [CrossRef]

160. Yoon, J.; Matsuo, Y.; Katsuta, A.; Jang, J.-H.; Matsuda, S.; Adachi, K.; Kasai, H.; Yokota, A. Haloferula rosea gen. nov., sp. nov., Haloferula harenae sp. nov., Haloferula phyci sp. nov., Haloferula helveola sp. nov. and Haloferula sargassicola sp. nov., five marine representatives of the family Verrucomicrobiaceae within the phylum 'Verrucomicrobia'. Int. J. Syst. Evol. Microbiol. 2008, 58, 2491-2500. [CrossRef] [PubMed]

161. Weiner, R.M.; Melick, M.; O’Neill, K.; Quintero, E. Hyphomonas adhaerens sp. nov., Hyphomonas johnsonii sp. nov. and Hyphomonas rosenbergii sp. nov., marine budding and prosthecate bacteria. Int. J. Syst. Evol. Microbiol. 2000, 50, 459-469. [CrossRef]

162. Tanasupawat, S.; Takehana, T.; Yoshida, S.; Hiraga, K.; Oda, K. Ideonella sakaiensis sp. nov., isolated from a microbial consortium that degrades poly(ethylene terephthalate). Int. J. Syst. Evol. Microbiol. 2016, 66, 2813-2818. [CrossRef]

163. Vancanneyt, M.; Nedashkovskaya, O.I.; Snauwaert, C.; Mortier, S.; Vandemeulebroecke, K.; Hoste, B.; Dawyndt, P.; Frolova, G.M.; Janssens, D.; Swings, J. Larkinella insperata gen. nov., sp. nov., a bacterium of the phylum 'Bacteroidetes' isolated from water of a steam generator. Int. J. Syst. Evol. Microbiol. 2006, 56, 237-241. [CrossRef] [PubMed]

164. Christensen, P.; Cook, F.D. Lysobacter, a new genus of nonfruiting, gliding bacteria with a high base ratio. Int. J. Syst. Evol. Microbiol. 1978, 28, 367-393. [CrossRef]

165. Takeuchi, M.; Hamana, K.; Hiraishi, A. Proposal of the genus Sphingomonas sensu stricto and three new genera, Sphingobium, Novosphingobium and Sphingopyxis, on the basis of phylogenetic and chemotaxonomic analyses. Int. J. Syst. Evol. Microbiol. 2001, 51, 1405-1417. [CrossRef] [PubMed]

166. Irgens, R.L.; Gosink, J.J.; Staley, J.T. Polaromonas vacuolata gen. nov., sp. nov., a psychrophilic, marine, gas vacuolate bacterium from Antarctica. Int. J. Syst. Evol. Microbiol. 1996, 46, 822-826. [CrossRef]

167. Larkin, J.M.; Williams, P.M. Runella slithyformis gen. nov., sp. nov., a curved, nonflexible, pink bacterium. Int. J. Syst. Evol. Microbiol. 1978, 28, 32-36. [CrossRef]

168. Pascual, J.; Wüst, P.K.; Geppert, A.; Foesel, B.U.; Huber, K.J.; Overmann, J. Novel isolates double the number of chemotrophic species and allow the first description of higher taxa in Acidobacteria subdivision 4. Syst. Appl. Microbiol. 2015, 38, 534-544. [CrossRef] [PubMed]

169. Albuquerque, L.; Simões, C.; Nobre, M.F.; Pino, N.M.; Battista, J.R.; Silva, M.T.; Rainey, F.A.; de Costa, M.S. Truepera radiovictrix gen. nov., sp. nov., a new radiation resistant species and the proposal of Trueperaceae fam. nov. FEMS Microbiol. Lett. 2005, 247, 161-169. [CrossRef]

170. Kulichevskaya, I.S.; Baulina, O.I.; Bodelier, P.L.E.; Rijpstra, W.I.C.; Damsté, J.S.S.; Dedysh, S.N. Zavarzinella formosa gen. nov., sp. nov., a novel stalked, Gemmata-like planctomycete from a Siberian peat bog. Int. J. Syst. Evol. Microbiol. 2009, 59, $357-364$. [CrossRef] [PubMed]

171. Strömpl, C. Anaeromusa. In Bergey's Manual of Systematics of Archaea and Bacteria; John Wiley \& Sons, Inc.: Hoboken, NJ, USA, 2015; pp. 1-2. [CrossRef] 
172. Del Dot, T.; Osawa, R.; Stackebrandt, E. Phascolarctobacterium faecium gen. nov, spec. nov., a novel taxon of the Sporomusa group of bacteria. Syst. Appl. Microbiol. 1993, 16, 380-384. [CrossRef]

173. Chen, S.; Niu, L.; Zhang, Y. Saccharofermentans acetigenes gen. nov., sp. nov., an anaerobic bacterium isolated from sludge treating brewery wastewater. Int. J. Syst. Evol. Microbiol. 2010, 60, 2735-2738. [CrossRef]

174. Möller, B.; Oßmer, R.; Howard, B.H.; Gottschalk, G.; Hippe, H. Sporomusa, a new genus of gram-negative anaerobic bacteria including Sporomusa sphaeroides spec. nov. and Sporomusa ovata spec. nov. Arch. Microbiol. 1984, 139, 388-396. [CrossRef]

175. Song, Y.; Könönen, E.; Rautio, M.; Liu, C.; Bryk, A.; Eerola, E.; Finegold, S.M. Alistipes onderdonkii sp. nov. and Alistipes shahii sp. nov., of human origin. Int. J. Syst. Evol. Microbiol. 2006, 56, 1985-1990. [CrossRef]

176. Li, T.; Guo, F.; Lin, Y.; Li, Y.; Wu, G. Metagenomic analysis of quorum sensing systems in activated sludge and membrane biofilm of a full-scale membrane bioreactor. J. Water Process. Eng. 2019, 32, 100952. [CrossRef]

177. Bai, Y.; Zhou, X.; Li, N.; Zhao, J.; Ye, H.; Zhang, S.; Yang, H.; Pi, Y.; Tao, S.; Han, D.; et al. In vitro fermentation characteristics and fiber-degrading enzyme kinetics of cellulose, arabinoxylan, $\beta$-glucan and glucomannan by pig fecal microbiota. Microorganisms 2021, 9, 1071. [CrossRef] [PubMed]

178. Abt, B.; Göker, M.; Scheuner, C.; Han, C.; Lu, M.; Misra, M.; Lapidus, A.; Nolan, M.; Lucas, S.; Hammon, N.; et al. Genome sequence of the thermophilic fresh-water bacterium Spirochaeta caldaria type strain $\left(\mathrm{H}^{\mathrm{T}}\right)$, reclassification of Spirochaeta caldaria, Spirochaeta stenostrepta, and Spirochaeta zuelzerae in the genus Treponema as Treponema caldaria comb. nov., Treponema stenostrepta comb. nov., and Treponema zuelzerae comb. nov., and emendation of the genus Treponema. Stand. Genom. Sci. 2013, 8, 88-105. [CrossRef]

179. Sun, Y.-T.; Zhou, N.; Wang, B.-J.; Liu, X.-D.; Jiang, C.-Y.; Ge, X.; Liu, S.-J. Vallitalea okinawensis sp. nov., isolated from Okinawa Trough sediment and emended description of the genus Vallitalea. Int. J. Syst. Evol. Microbiol. 2019, 69, 404-410. [CrossRef]

180. Stams, A.J.M.; Hansen, T.A. Fermentation of glutamate and other compounds by Acidaminobacter hydrogenoformans gen. nov. sp. nov., an obligate anaerobe isolated from black mud. Studies with pure cultures and mixed cultures with sulfate-reducing and methanogenic bacteria. Arch. Microbiol. 1984, 137, 329-337. [CrossRef]

181. Matthies, C.; Evers, S.; Ludwig, W.; Schink, B. Anaerovorax odorimutans gen. nov., sp. nov., a putrescine-fermenting, strictly anaerobic bacterium. Int. J. Syst. Evol. Microbiol. 2000, 50, 1591-1594. [CrossRef]

182. Su, X.-L.; Tian, Q.; Zhang, J.; Yuan, X.-Z.; Shi, X.-S.; Guo, R.-B.; Que, Y.-L. Acetobacteroides hydrogenigenes gen. nov., sp. nov., an anaerobic hydrogen-producing bacterium in the family Rikenellaceae isolated from a reed swamp. Int. J. Syst. Evol. Microbiol. 2014, 64, 2986-2991. [CrossRef]

183. Yang, G.; Wang, J. Changes in microbial community structure during dark fermentative hydrogen production. Int. J. Hydrogen Energy 2019, 44, 25542-25550. [CrossRef]

184. Lu, J.-H.; Chen, C.; Huang, C.; Lee, D.-J. Glucose fermentation with biochar-amended consortium: Microbial consortium shift. Bioengineered 2020, 11, 272-280. [CrossRef]

185. Haack, S.K.; Breznak, J.A. Cytophaga xylanolytica sp. nov., a xylan-degrading, anaerobic gliding bacterium. Arch. Microbiol. 2004, 159, 6-15. [CrossRef]

186. Haack, F.S.; Poehlein, A.; Kröger, C.; Voigt, C.A.; Piepenbring, M.; Bode, H.B.; Daniel, R.; Schäfer, W.; Streit, W.R. Molecular Keys to the Janthinobacterium and Duganella spp. interaction with the plant pathogen Fusarium graminearum. Front. Microbiol. 2016, 7, 1668. [CrossRef]

187. Starr, M.P.; Baigent, N.L. Parasitic interaction of Bdellovibrio bacteriovorus with other bacteria. J. Bacteriol. 1966, 91, $2006-2017$. [CrossRef]

188. Kiss, H.; Nett, M.; Domin, N.; Martin, K.; Maresca, J.A.; Copeland, A.; Lapidus, A.; Lucas, S.; Berry, K.W.; Del Rio, T.G.; et al. Complete genome sequence of the filamentous gliding predatory bacterium Herpetosiphon aurantiacus type strain $\left(114-95^{\mathrm{T}}\right)$. Stand. Genom. Sci. 2011, 5, 356-370. [CrossRef]

189. Esson, K.C.; Lin, X.; Kumaresan, D.; Chanton, J.P.; Murrell, J.C.; Kostka, J.E. Alpha- and gammaproteobacterial methanotrophs codominate the active methane-oxidizing communities in an acidic boreal peat bog. Appl. Environ. Microbiol. 2016, 82, $2363-2371$. [CrossRef] [PubMed]

190. Kröber, E.; Cunningham, M.R.; Peixoto, J.; Spurgin, L.; Wischer, D.; Kruger, R.; Kumaresan, D. Comparative genomics analyses indicate differential methylated amine utilization trait within members of the genus Gemmobacter. Environ. Microbiol. Rep. 2021, 13, 195-208. [CrossRef] [PubMed]

191. Jimenez-Infante, F.; Ngugi, D.K.; Vinu, M.; Alam, I.; Kamau, A.A.; Blom, J.; Bajic, V.B.; Stingl, U. Comprehensive genomic analyses of the OM43 clade, including a novel species from the Red Sea, indicate ecotype differentiation among marine methylotrophs. Appl. Environ. Microbiol. 2016, 82, 1215-1226. [CrossRef]

192. Zhao, Y.; Jiang, B.; Tang, X.; Liu, S. Metagenomic insights into functional traits variation and coupling effects on the anammox community during reactor start-up. Sci. Total Environ. 2019, 687, 50-60. [CrossRef] [PubMed]

193. Esposito, A.; Pagnanelli, F.; Lodi, A.; Solisio, C.; Vegliò, F. Biosorption of heavy metals by Sphaerotilus natans: An equilibrium study at different $\mathrm{pH}$ and biomass concentrations. Hydrometallurgy 2001, 60, 129-141. [CrossRef]

194. Fernández-Trujillo, J.P.; Martínez, J.A.; Salmerón, M.C.; Artés, F. Isolation of Acremonium species causing postharvest decay of peaches of Spain. Plant Dis. 1997, 81, 958. [CrossRef]

195. Woudenberg, J.H.C.; Groenewald, J.Z.; Binder, M.; Crous, P.W. Alternaria redefined. Stud. Mycol. 2013, 75, 171-212. [CrossRef] [PubMed] 
196. Crous, P.W.; Groenewald, J.Z. A phylogenetic re-evaluation of Arthrinium. IMA Fungus 2013, 4, 133-154. [CrossRef] [PubMed]

197. de Vries, R.P.; Visser, J. Aspergillus enzymes involved in degradation of plant cell wall polysaccharides. Microbiol. Mol. Biol. Rev. 2001, 65, 497-522. [CrossRef] [PubMed]

198. Gleason, F.H.; Kagami, M.; Lefevre, E.; Sime-Ngando, T. The ecology of chytrids in aquatic ecosystems: Roles in food web dynamics. Fungal Biol. Rev. 2008, 22, 17-25. [CrossRef]

199. Sert, H.B.; Sümbül, H.; Sterflinger, K. A new species of Capnobotryella from monument surfaces. Mycol. Res. 2007, 111, 1235-1241. [CrossRef]

200. Rungjindamai, N.; Sakayaroj, J.; Plaingam, N.; Somrithipol, S.; Jones, E.B.G. Putative basidiomycete teleomorphs and phylogenetic placement of the coelomycete genera: Chaetospermum, Giulia and Mycotribulus based on nu-rDNA sequences. Mycol. Res. 2008, 112, 802-810. [CrossRef]

201. Reisert, P.S.; Fuller, M.S. Decomposition of chitin by Chytriomyces species. Mycologia 1962, 54, 647-657. [CrossRef]

202. Bensch, K.; Braun, U.; Groenewald, J.Z.; Crous, P.W. The genus Cladosporium. Stud. Mycol. 2012, 72, 1-401. [CrossRef]

203. Zuccaro, A.; Summerbell, R.C.; Gams, W.; Schroers, H.-J.; Mitchell, J.I. A new Acremonium species associated with Fucus spp., and its affinity with a phylogenetically distinct marine Emericellopsis clade. Stud. Mycol. 2004, 50, 283-297.

204. Longcore, J.E. Morphology and zoospore ultrastructure of Entophlyctis luteolus sp. nov. (Chytridiales): Implications for chytrid taxonomy. Mycologia 1995, 87, 25-33. [CrossRef]

205. Fracchia, S.; Garcia-Romera, I.; Godeas, A.; Ocampo, J.A. Effect of the saprophytic fungus Fusarium oxysporum on arbuscular mycorrhizal colonization and growth of plants in greenhouse and field trials. Plant Soil 2000, 223, 175-184. [CrossRef]

206. Varnaitè, R.; Raudonienè, V.; Bridžiuvienè, D. Enzymatic biodegradation of lignin-cellulose complex in plant origin material. Mater. Sci. 2011, 17, 99-103. [CrossRef]

207. Giraldo, A.; Hernández-Restrepo, M.; Crous, P.W. New plectosphaerellaceous species from Dutch garden soil. Mycol. Prog. 2019, 18, 1135-1154. [CrossRef]

208. Fedosova, A.G.; Popov, E.S.; Lizon, P.; Kučera, V. Towards an understanding of the genus Glutinoglossum with emphasis on the Glutinoglossum glutinosum species complex (Geoglossaceae, Ascomycota). Persoonia 2018, 41, 18-38. [CrossRef] [PubMed]

209. Landell, M.F.; Brandão, L.R.; Barbosa, A.C.; Ramos, J.P.; Safar, S.V.B.; Gomes, F.C.O.; Sousa, F.M.P.; Morais, P.B.; Broetto, L.; Leoncini, O.; et al. Hannaella pagnoccae sp. nov., a tremellaceous yeast species isolated from plants and soil. Int. J. Syst. Evol. Microbiol. 2014, 64, 1970-1977. [CrossRef] [PubMed]

210. Zhang, Y.; Liu, Y.; Zhou, Y.; Zhang, X.; Cui, B.-K.; He, S.; Fournier, J. Helicascus gallicus sp. nov., a new freshwater pleosporalean ascomycete from France. Phytotaxa 2014, 183, 183-192. [CrossRef]

211. White, J.F., Jr.; Morgan-Jones, G.; Morrow, A.C. Taxonomy, life cycle, reproduction and detection of Acremonium endophytes. Agric. Ecosyst. Environ. 1993, 44, 13-37. [CrossRef]

212. Calabon, M.S.; Jones, E.B.G.; Hyde, K.D.; Boonmee, S.; Tibell, S.; Tibell, L.; Pang, K.-L.; Phookamsak, R. Phylogenetic assessment and taxonomic revision of Halobyssothecium and Lentithecium (Lentitheciaceae, Pleosporales). Mycol. Prog. 2021, 20, 701-720. [CrossRef]

213. Li, F.; Chen, L.; Redmile-Gordon, M.; Zhang, J.; Zhang, C.; Ning, Q.; Li, W. Mortierella elongata's roles in organic agriculture and crop growth promotion in a mineral soil. Land Degrad. Dev. 2018, 29, 1642-1651. [CrossRef]

214. Marano, A.V.; Pires-Zottarelli, C.L.A.; Barrera, M.D.; Steciow, M.M.; Gleason, F.H. Diversity, role in decomposition, and succession of zoosporic fungi and straminipiles on submerged decaying leaves in a woodland stream. Hydrobiologia 2011, 659, 93-109. [CrossRef]

215. Machouart, M.; Samerpitak, K.; de Hoog, G.S.; Gueidan, C. A multigene phylogeny reveals that Ochroconis belongs to the family Sympoventuriaceae (Venturiales, Dothideomycetes). Fungal Divers. 2014, 65, 77-88. [CrossRef]

216. Ali, B.R.S.; Zhou, L.; Graves, F.M.; Freedman, R.B.; Black, G.W.; Gilbert, H.J.; Hazlewood, G.P. Cellulases and hemicellulases of the anaerobic fungus Piromyces constitute a multiprotein cellulose-binding complex and are encoded by multigene families. FEMS Microbiol. Lett. 1995, 125, 15-21. [CrossRef]

217. Khan, Z.; Ahmad, S.; Kapila, K.; Ramaswamy, N.V.; Alath, P.; Joseph, L.; Chandy, R. Pyrenochaeta romeroi: A causative agent of phaeohyphomycotic cyst. J. Med. Microbiol. 2011, 60, 842-846. [CrossRef] [PubMed]

218. Wang, Q.-M.; Bai, F.-Y. Four new yeast species of the genus Sporobolomyces from plant leaves. FEMS Yeast Res. 2004, 4, 579-586. [CrossRef] [PubMed]

219. Suetrong, S.; Rungjindamai, N.; Sommai, S.; Rung-Areerate, P.; Somrithipol, S.; Jones, E.B.G. Wiesneriomyces a new lineage of Dothideomycetes (Ascomycota) basal to Tubeufiales. Phytotaxa 2014, 176, 283-297. [CrossRef]

220. Corsaro, D.; Walochnik, J.; Venditti, D.; Steinmann, J.; Müller, K.-D.; Michel, R. Microsporidia-like parasites of amoebae belong to the early fungal lineage Rozellomycota. Parasitol. Res. 2014, 113, 1909-1918. [CrossRef] [PubMed]

221. Shin, W.; Boo, S.M.; Longcore, J.E. Entophlyctis apiculata, a chytrid parasite of Chlamydomonas sp. (Chlorophyceae). Can. J. Bot. 2011, 79, 1083-1089. [CrossRef]

222. Letcher, P.; Powell, M.J. Phylogenetic position of Phlyctochytrium planicorne (Chytridiales, Chytridiomycota) based on zoospore ultrastructure and partial nuclear LSU rRNA gene sequence analysis. Nova Hedwig. 2005, 80, 135-146. [CrossRef]

223. Gromov, B.V.; Pljusch, A.V.; Mamkaeva, K.A. Cultures of Rhizophydium spp. (Chytridiales)-parasites of chlorococcalean algae. Algol. Stud. 1999, 95, 115-123. [CrossRef] 
224. Hirotani-Akabane, E.; Saikawa, M. Germination and morphology of zygospores in two Cochlonema and one Acaulopage species. Mycologia 2010, 102, 39-43. [CrossRef]

225. Karpov, S.A.; Mamkaeva, M.A.; Benzerara, K.; Moreira, D.; López-García, P. Molecular phylogeny and ultrastructure of Aphelidium aff. melosirae (Aphelida, Opisthosporidia). Protist 2014, 165, 512-526. [CrossRef] [PubMed]

226. Karpov, S.A.; Cvetkova, V.S.; Annenkova, N.V.; Vishnyakov, A.E. Kinetid structure of Aphelidium and Paraphelidium (Aphelida) suggests the features of the common ancestor of fungi and Opisthosporidia. J. Eukaryot. Microbiol. 2019, 66, 911-924. [CrossRef] [PubMed]

227. Pereira, P.T.; de Carvalho, M.M.; Gírio, F.M.; Roseiro, J.C.; Amaral-Collaço, M.T. Diversity of microfungi in the phylloplane of plants growing in a Mediterranean ecosystem. J. Basic Microbiol. 2002, 42, 396-407. [CrossRef]

228. Srisuk, N.; Nutaratat, P.; Surussawadee, J.; Limtong, S. Yeast communities in sugarcane phylloplane. Microbiology 2019, 88, 353-369. [CrossRef]

229. Limtong, S.; Kaewwichian, R. The diversity of culturable yeasts in the phylloplane of rice in Thailand. Ann. Microbiol. 2014, 65, 667-675. [CrossRef]

230. Into, P.; Pontes, A.; Sampaio, J.P.; Limtong, S. Yeast diversity associated with the phylloplane of corn plants cultivated in Thailand. Microorganisms 2020, 8, 80. [CrossRef]

231. Ozimek, E.; Hanaka, A. Mortierella species as the plant growth-promoting fungi present in the agricultural soils. Agriculture 2021, 11, 7. [CrossRef]

232. Ma, L.-J.; Geiser, D.M.; Proctor, R.H.; Rooney, A.P.; O’Donnell, K.; Trail, F.; Gardiner, D.M.; Manners, J.M.; Kazan, K. Fusarium pathogenomics. Annu. Rev. Microbiol. 2013, 67, 399-416. [CrossRef]

233. Que, Y.; Xu, L.; Wu, Q.; Liu, Y.; Ling, H.; Liu, Y.; Zhang, Y.; Guo, J.; Su, Y.; Chen, J.; et al. Genome sequencing of Sporisorium scitamineum provides insights into the pathogenic mechanisms of sugarcane smut. BMC Genom. 2014, 15, 996. [CrossRef]

234. Corsaro, D.; Köhsler, M.; Wylezich, C.; Venditti, D.; Walochnik, J.; Michel, R. New insights from molecular phylogenetics of amoebophagous fungi (Zoopagomycota, Zoopagales). Parasitol. Res. 2018, 117, 157-167. [CrossRef]

235. Persmark, L.; Marban-Mendoza, N.; Jansson, H.-B. Nematophagous fungi from agricultural soils of Central America. Nematropica 1995, 25, 117-124.

236. Rodrigues, L.; Bicudo, D. Similarity among periphyton algal communities in a lentic-lotic gradient of the upper Paraná river floodplain, Brazil. Rev. Bras. Bot. 2001, 24, 235-248. [CrossRef]

237. Krebs, R.A.; Prescott, T.J.; Clapham, W.B.; Klarer, D.M. Freshwater mussel assemblages at the lotic-lentic interface along Lake Erie. Am. Malacol. Bull. 2018, 36, 31-41. [CrossRef]

238. Kollár, J.; Fránková, M.; Hašler, P.; Letáková, M.; Poulíčková, A. Epiphytic diatoms in lotic and lentic waters-Diversity and representation of species complexes. Fottea 2015, 15, 259-271. [CrossRef] 